\title{
Covid-19, risco de backsliding e reação dos Tribunais Constitucionais: um contraste entre Itália e Brasil ${ }^{1}$
}

\author{
Covid-19, risk of backsliding and response of the Constitutional \\ Courts: a contrast between Italy and Brazil
}

Covid-19, riesgo de backsliding y reacción de los Tribunales

Constitucionales: un contraste entre Italia y Brasil

\author{
Valerio de Oliveira Mazzuoli \\ Universidade Federal de Mato Grosso (Cuiabá, MT, Brasil) \\ ORCID: https://orcid.org/0000-0001-8313-9136 \\ E-mail:mazzuoli@ufmt.br
}

\author{
Hugo Abas Frazão \\ Università di Pisa (Pisa, Toscana, Itália) \\ ORCID: https://orcid.org/0000-0003-1511-0010 \\ E-mail: h.abasfrazao@studenti.unipi.it
}

\section{Resumo}

Este artigo apresenta a pandemia da Covid-19 como um fenômeno de fato que potencialmente produz riscos de backsliding democrático em matéria de concentração de poder político, levando ao fortalecimento excessivo das funções do governo e à redução das garantias constitucionais existentes. O problema da presente investigação é saber que papel a Corte (Suprema ou) Constitucional deve cumprir a fim de evitar violações à rule of law por parte dos poderes do Estado no cenário da pandemia. Tem-se por hipótese que a possibilidade de a

\footnotetext{
MAZZUOLI, Valerio de Oliveira; FRAZÃO, Hugo Abas. Covid-19, risco de backsliding e reação dos tribunais constitucionais: um contraste entre Itália e Brasil. Suprema: revista de estudos constitucionais, Brasília, v. 1, n. 2, p. 323-362, jul./dez. 2021.

2 Professor-associado da Faculdade de Direito da Universidade Federal de Mato Grosso - UFMT. Pós-Doutor em Ciências Jurídico-Políticas pela Universidade Clássica de Lisboa. Doutor summa cum laude em Direito Internacional pela Universidade Federal do Rio Grande do Sul - UFRGS. Membro-titular da Sociedade Brasileira de Direito Internacional - SBDI. Membro Consultivo da Comissão Especial de Direito Internacional do Conselho Federal da Ordem dos Advogados do Brasil - CFOAB. Currículo Lattes: http://lattes.cnpq.br/9864274763325158.

3 Juiz Federal no TRF da 1a Região. Visiting Researcher na Sciences Po Paris (França). Doutorando em Giustizia costituzionale na Università di Pisa (Itália). Mestre em Direito Constitucional pela Pontifícia Universidade Católica de São Paulo (PUC-SP). Currículo Lattes: http://lattes.cnpq.br/3729285005820627.
} 
justiça constitucional exercer um poder jurisdicional, transitoriamente, mais forte ou mais expansivo aumenta quando o fato da pandemia ameaça o equilíbrio de poderes e a proteção dos direitos fundamentais. A pesquisa tomará como referência os sistemas jurídicos da Itália e do Brasil, os quais, apesar das diferenças em termos de sistema de governo e de forma de Estado, adotam o regime da democracia constitucional liberal e têm suas respectivas justiças constitucionais - a saber, a Corte Constitucional italiana e o Supremo Tribunal Federal brasileiro - em estágio de crescente valorização perante o quadro das instituições de Estado. A metodologia utilizada é orientada pelos fundamentos teóricos, áreas de comparação e procedimentos de investigação que apoiam a escolha do método comparado.

\section{Palavras-chave}

Direito Constitucional Comparado; Covid-19; backsliding democrático; Corte Constitucional italiana; Supremo Tribunal Federal.

\section{Suimário}

1. Introdução. 2. Por que um diálogo transnacional entre Itália e Brasil? 3. Backsliding: a Covid-19 e o temor de um recuo democrático. 4. Experiência da Itália: direção unitária da crise e presença de contrapoder político. 4.1 Disfunções políticas da colaboração no regionalismo italiano. 4.2 Falta de standards parlamentares, emprego de standards científicos. 4.3 Resposta discreta da justiça constitucional. 5. Experiência do Brasil: direção fragmentada da crise e dificuldade de contrapoder político. 5.1 Disfunções políticas do federalismo de cooperação brasileiro. 5.2 Falta de gestão política orientada por standards políticos ou científicos e a necessidade de uma decisão manipulativa aditiva por parte do STF. 5.3 Resposta proativa da justiça constitucional. 6. Variação entre níveis de resposta dos tribunais constitucionais: uma salvaguarda para a rule of law. 7. Conclusão.

\section{Abstract}

This article presents the Covid-19 pandemic as a de facto phenomenon that potentially produces risks of democratic backsliding regarding the concentration of political power, potentially leading to the over-strengthening of government functions and the reduction of existing constitutional guarantees. The problem of the present research is to find out what role the (Supreme or) Constitutional Court should play in order to avoid violations of the rule of law by the branches of state in the scenario of the mentioned pandemic. It is hypothesized that the possibility of the constitutional justice exercising a stronger or more expansive 
jurisdictional power temporarily increases when the fact of the pandemic threatens the balance of powers and the fundamental rights protection. This research will take as reference the legal systems of Italy and Brazil, which, despite the differences in terms of government system and state form, adopt the liberal constitutional democracy regime and have their respective constitutional courts - namely the Italian Constitutional Court and the Brazilian Supreme Federal Court - in a stage of increasing valorization before the framework of state institutions. The methodology used in this research is guided by the theoretical foundations, areas of comparison and research procedures, which support the choice of the comparative method.

\section{Keywords}

Comparative Constitutional Law; Covid-19; democratic backsliding; Italian Constitutional Court; Brazilian Supreme Court.

\section{Contents}

1. Introduction. 2. Why a transnational dialogue between Italy and Brazil? 3. Backsliding: Covid-19 and the threat of a democratic backlash. 4. Italy's experience: unitary direction of the crisis and existence of a political counterpower. 4.1 Political dysfunctions of collaboration in Italian regionalism. 4.2 Lack legislative standards, use of scientific standards. 4.3 Self-restrained response from constitutional justice. Brazil's Experience: Fragmented direction of the crisis and difficulty of political counterpower 5.1 Political dysfunctions of Brazilian cooperative federalism 5.2 Lack of political and scientific standards and the necessity of an additive manipulative ruling by the STF. 5.3 Prominent response of the constitutional justice. 6. Variations between constitutional courts' levels of responsiveness: a safeguard for the rule of law. 7. Conclusion.

\section{Resuimen}

Este artículo presenta la pandemia de Covid-19 como un fenómeno de facto que potencialmente produce riesgos de backsliding democrático en lo que respecta a la concentración del poder político, lo que lleva al fortalecimiento excesivo de las funciones gubernamentales y a la reducción de las garantías constitucionales existentes. El problema de la presente investigación es saber qué papel debe desempeñar el Tribunal (Supremo o) Constitucional para evitar las violaciones del rule of law por parte de los poderes del Estado en el escenario de la pandemia. Se plantea la hipótesis de que la posibilidad de que la justicia constitucional ejerza un poder jurisdiccional transitoriamente más fuerte o más expansivo aumenta cuando el hecho de la pandemia amenaza el equilibrio de poderes y la protección 
de los derechos fundamentales. La investigación tomará como referencia los sistemas jurídicos de Italia y Brasil, que, a pesar de las diferencias en cuanto al sistema de gobierno y la forma de Estado, adoptan el régimen de la democracia constitucional liberal y tienen sus respectivos tribunales constitucionales - a saber, el Tribunal Constitucional italiano y el Tribunal Supremo brasileño - en una etapa de creciente valorización ante el marco de las instituciones estatales. La metodología utilizada se guía por los fundamentos teóricos, las áreas de comparación y los procedimientos de investigación que apoyan la elección del método comparativo.

\section{Palabras clave}

Derecho Constitucional Comparado; Covid-19; backsliding democrático; Tribunal Constitucional italiano; Tribunal Supremo.

\section{Indice}

1. Introducción. 2. ¿Por qué un diálogo transnacional entre Italia y Brasil? 3. Backsliding: Covid-19 y el miedo al retroceso democrático. 4. La experiencia de Italia: dirección unitaria de la crisis y presencia de un contrapoder político. 4.1 Disfunciones políticas de la colaboración en el regionalismo italiano. 4.2 Falta de standards parlamentarios, uso de standards científicos. 4.3 Respuesta discreta de la justicia constitucional. 5. La experiencia de Brasil: dirección fragmentada de la crisis y dificultad del contrapoder político 5.1 Disfunciones políticas del federalismo brasileño de cooperación 5.2 Falta de gestión política guiada por standards políticos o científicos y necesidad de una decisión manipuladora aditiva por parte del STF. 5.3 Respuesta proactiva de la justicia constitucional. 6. Variación entre los niveles de respuesta de los tribunales constitucionales: una salvaguarda para el Estado de Derecho. 7 Conclusión.

\section{Introdução}

Em meio a outros perfis de democracia constitucional que se apresentam no cenário global, os de vieses liberais têm-se mostrado mais aptos à compreensão do que se nomina regime democrático, justificando-se não apenas pelo nível de desenvolvimento socioeconômico ou de promoção dos direitos humanos, senão também e principalmente pelo controle que o povo realiza sobre o governo. ${ }^{4}$ Por

\footnotetext{
${ }^{4}$ É preciso ter em mente, por exemplo, que o princípio da soberania popular que caracteriza o Estado socialista não é interpretado para o fim de estabelecer a divisão de poderes ou de qualquer equilíbrio entre as instituições públicas. Na
} 
isso, o que diferencia um sistema jurídico liberal daqueles considerados iliberais não é a ideia de "governo do povo" - que pode ser constantemente manipulada por populismos, para colocar uma parte da sociedade contra outra -, mas de "governo fiscalizado pelo povo" (BARBERIS, 2020, p. 17). Desse modo, não apenas os órgãos de representação política devem ser fortalecidos, mas também aqueles de natureza contramajoritária, como os juízes e os demais órgãos do Estado vinculados à administração da Justiça, pois somente assim as minorias preservam a proteção de seus direitos mesmo que venham a se colocar em oposição ao governo.

Em linhas gerais, para medir a saúde democrática, o princípio da rule of law aparece como relevante elemento de legitimação da democracia liberal, ao assumir uma função mais objetiva e menos sujeita à manipulação autoritária. Esse princípio será adotado neste ensaio à luz de um enfoque processual ou formal. Embora as tradições jurídicas tenham pretendido dar significados parcialmente diferentes à rule of law, a exemplo de uma acepção substancial que pressupõe o cumprimento de valores materiais, o fundamento comum da rule of law reside na ideia de tornar o exercício do poder político menos arbitrário, mais previsível e mais impessoal (cf. WALDRON, 2020). Quanto mais se desenvolve o princípio da rule of law, mais alto é o estágio de democratização e constitucionalismo em um determinado sistema jurídico.

Entretanto, a pandemia da Covid-19 vem colocando o constitucionalismo liberal em apuros, devido à ausência de respostas capazes de resolver os problemas da contaminação sanitária, do agravamento dos sintomas nos pacientes acometidos pela doença e dos efeitos socioeconômicos gerados em todas as latitudes do globo. O cenário de incerteza acende preocupação quanto ao uso excessivo do poder de governo para administrar a crise. Não obstante serem enormes os riscos de morte da população, as instâncias políticas não podem valer-se do argumento de proteção da sociedade para acrescentar em si mesmas um excessivo poder, ao ponto de tal prática não se legitimar perante os pressupostos da rule of law. Ademais, isso abre a possibilidade de que, mesmo no fim do estado de emergência, o accentramento governativo possa perdurar, dando ao Estado

realidade, a aplicação do princípio de representação nesse tipo de Estado implica que o poder soberano é concentrado e não difuso, o que exclui, desde o início, qualquer restrição à competência geral do parlamento. As democracias pluralistas, por outro lado, mais receptivas aos problemas ligados à multiplicidade de expressões da vontade popular, desenvolvem um sistema de contrapoder para evitar qualquer forma de abuso de poder (cf. DELPÉRÉE, 1988, p. 99). 
constitucional um passo atrás em direção ao estado de exceção. Tal fenômeno de recuo institucional será denominado backsliding democrático.

Neste artigo, a pandemia da Covid-19 é apresentada como um fenômeno de facto que potencialmente produz riscos de backsliding democrático no tocante à concentração de poder político. Esses mesmos riscos, que dentro das democracias ocidentais implicam tendencialmente o advento de regimes de democraturas ${ }^{5}$, podem levar ao fortalecimento excessivo das funções do governo e à redução das garantias constitucionais existentes.

Diante dessa conjuntura, que papel a Corte (Suprema ou) Constitucional deve cumprir a fim de evitar violações à rule of law por parte dos poderes do Estado no cenário da mencionada pandemia? Tem-se como hipótese a tal problema de pesquisa que a possibilidade de a justiça constitucional exercer, transitoriamente, um poder jurisdicional mais forte ou mais expansivo aumenta quando o fato da pandemia ameaça o equilíbrio de poderes e a tutela dos direitos fundamentais.

Esta investigação tem como referência os sistemas jurídicos da Itália e do Brasil, os quais, apesar das diferenças em termos de sistema de governo e forma de Estado, adotam o regime liberal da democracia constitucional e têm os respectivos Tribunais Constitucionais - a saber, a Corte Constitucional italiana e o Supremo Tribunal Federal (STF) brasileiro - numa fase de crescente valorização perante o quadro das instituições estatais. A metodologia utilizada é orientada pelos fundamentos teóricos, áreas de comparação e procedimentos de pesquisa, que apoiam a escolha do método comparado.

\section{Por que um diálogo transnacional entre Itália e Brasil?}

A escolha dessas duas ordens constitucionais para fins de comparação ocorre porque, tanto na Itália quanto no Brasil, a pandemia provocou fortes impactos com relação ao número de contágio e ao número de mortos. Além disso, à medida que ambos os países registravam os avanços do novo coronavírus, as

\footnotetext{
${ }^{5}$ Entre as características frequentemente comuns às democraturas estão as "exceções à Constituição", a introdução das emendas constitucionais com o propósito de reforçar poderes governamentais e reduzir garantias institucionais, bem como alongar ou multiplicar a duração dos mandatos presidenciais. Nesse último caso, admite-se invenção de métodos camuflados de perpetuação no poder, a citar o caso em que o líder e seu discípulo alternam os cargos de Presidente e Primeiro-Ministro, permitindo que o líder governe de maneira constante. Cf. SPADARO, 2020, p. 3895.
} 
suas formas de governo também padeciam do risco de uma certa sobreposição do Executivo em relação ao Parlamento, deixando as decisões para conter a emergência sanitária excessivamente a cargo do governante. Esse problema, aliás, foi posto em evidência pela doutrina constitucionalista como um fato de potencial desequilíbrio entre os poderes. ${ }^{6}$

Perante essa dificuldade interorgânica, ${ }^{7}$ os Tribunais Constitucionais da Itália e do Brasil foram chamados a se manifestar no contexto da pandemia, oferecendo níveis de resposta particularmente diferentes de acordo com os eventuais riscos de assimetria relativamente à rule of law. A fim de melhor perceber esse fenômeno, pretende-se confrontar as atuações das Cortes (Supremas ou) Constitucionais de ambos os países em relação a situações jurídicas da crise sanitária. Assim sendo, este estudo considera que a incursão do poder jurisdicional no poder político pode ter sido maior ou menor, dependendo da natureza e eficácia das medidas político-administrativas adotadas para a gestão pandêmica e da presença de outros instrumentos de contrapoder para fiscalizar as ameaças de excesso por parte das instâncias governamentais.

É igualmente relevante considerar a distinção entre as peculiaridades estruturais reservadas a cada um dos Tribunais analisados no presente artigo. ${ }^{8}$ É dizer, ao longo da sua trajetória, a Corte Constitucional italiana tem desenvolvido diversas tipologias decisórias de nível técnico refinado, que têm servido de referência para estudos sobre justiça constitucional. ${ }^{9}$ No entanto, em aspectos estruturais mais específicos, tal Tribunal apresenta delimitações estreitas,

\footnotetext{
${ }^{6}$ Quanto ao cenário brasileiro, os autores do presente artigo científico analisaram a tentativa de concentração das decisões nas mãos do Presidente da República em Fascículo especial monográfico lançado por ocasião do Seminario di Diritto Pubblico Comparato dell'Università di Pisa, ocorrido em 8 de maio de 2020 e organizado por Rolando Tarchi com o propósito de discutir as experiências de países democráticos no contexto da gestão da pandemia da Covid-19. Já quanto ao cenário italiano, vale conferir como Romboli (2020c, p. 525-528) afronta o impacto da pandemia sobre a forma de governo nacional, salientando a concentração dos poderes no Executivo e a atuação desacreditada e silenciosa do Parlamento. Também é interessante conferir o estudo produzido por LIPPOLIS (2021) no que se refere à relação entre Parlamento e Governo italiano durante a pandemia.

Essa questão se soma ainda aos esforços por colaboração entre órgãos subnacionais verticalmente relacionados, tema que foi explorado no artigo científico "Lições ao constitucionalismo subnacional brasileiro e italiano a partir das normas de emergência no combate à Covid-19”, escrito pelos autores deste ensaio (cf. MAZZUOLI; FRAZAO, 2021).

8 Para uma compreensão mais detalhada dos modelos de justiça constitucional e como circulam no cenário dos sistemas jurídicos nacionais, cf. PEGORARO, 2005.

9 Alguns exemplos de tipologias decisórias resultantes da experiência concreta da Corte Constitucional italiana são as sentenças interpretativas, as interpretações constitucionalmente conforme, as sentenças manipulativas e, mais recentemente, a denominada sentença em duas fases, tomada no Caso Cappato. A esse respeito, cf. ROMBOLI, 2020a, p. 36 ss.
} 
isto é: o objeto sujeito ao controle de constitucionalidade no âmbito da Corte Constitucional italiana é limitado às leis e aos atos com força de lei (art. $134^{10} \mathrm{e}$ art. 136, $\$ 1^{\mathrm{o}^{11}}$, da Constituição de 1947), verificados sob o juízo abstrato ou em tese. Na mesma linha, as vias de acesso à Corte são também restritas a apenas dois procedimentos: o procedimento em via incidental ${ }^{12}$ e o em via principal $^{13}$.

Por outro lado, o STF realiza o controle de constitucionalidade de forma mais abrangente porque examina a legitimidade não só de leis e atos normativos primários, mas também de outros atos do poder público, seja em sede de juízo abstrato/concentrado ou em sede de juízo concreto/incidental (art. 102 da Constituição de 1988). Além disso, a Suprema Corte brasileira pode combinar elementos de ambas as perspectivas de controle, dando origem ao fenômeno da abstrativização do controle concreto ou da concretização do controle abstrato. ${ }^{14}$ Essa ampla competência vem ainda implementada por numerosos tipos de procedimentos, ao contrário de como ocorre no exemplo italiano.

Considerando os elementos de distinção apresentados, é possível assinalar que o STF tende a fiscalizar mais de perto os atos de governo ou atos regulatórios a partir de uma percepção concretizadora do direito, ao passo que a Corte Constitucional italiana não é dotada dessa mesma envergadura institucional. Tal panorama deverá ser levado em conta a respeito dos resultados da incursão da justiça constitucional na gestão da pandemia nos dois países.

Do ponto de vista substancial, este estudo propõe que as ameaças de acumulação de poder político causadas pela pandemia da Covid-19 conferem aos Tribunais Constitucionais da Itália e do Brasil o ônus de observar o critério de legitimação da rule of law não somente sob o aspecto objetivo, mas também sob o

\footnotetext{
${ }_{10}$ Verbis: "O Tribunal Constitucional julga: sobre as controvérsias relativas à legitimidade constitucional das leis e dos atos, tento força de lei, do Estado e das Regiões; sobre os conflitos de atribuição entre os poderes do Estado e sobre aqueles entre o Estado e as Regiões, e entre as Regiões; sobre as acusações fomentadas contra o Presidente da República; em conformidade com a Constituição”.

${ }^{11}$ Verbis: "Quando o Tribunal declara a ilegitimidade constitucional de uma norma de lei ou de um ato tendo força de lei, a norma cessa de ter eficácia a partir do dia seguinte à publicação da decisão”.

12 A questão de ilegitimidade é submetida à Corte Constitucional por um juiz comum como um incidente que nasce no decurso de um processo judicial em andamento (cf. CARETTI; SIERVO, 2017, p. 436).

13 A Corte Constitucional recebe diretamente demanda relativa a conflito de atribuição entre Estado e Região, caracterizado pelo fato de uma lei estatal ou regional estar em contraste com os critérios de competência legislativa constitucionalmente fixados (cf. CARETTI; SIERVO, 2017, p. 440).

${ }^{14}$ A exemplo do que se deu nos julgamentos da ADI 3.406 (STF, ADI 3406, Tribunal Pleno, Rel. Min. Rosa Weber, j. 29 nov. 2017); e da ADI 3.470 (STF, ADI 3470, Tribunal Pleno, Rel. Min. Rosa Weber, j. 29 nov. 2017).
} 
aspecto contextual, isto é, de acordo com o grau de dificuldade que as instituições políticas e administrativas possuem para controlar a gestão da presente crise sanitária. Assim, quanto mais difícil for o mencionado controle, maior deve ser a resposta a ser dada pela respectiva Corte (Suprema ou) Constitucional.

Como materiais de análise, além dos atos normativos políticos emanados, o cenário italiano será compreendido a partir das seguintes decisões da Corte Constitucional: a Ordinanza n. 4, de 14 de janeiro de $2021^{15}$, a Sentença n. 37, publicada em 17 de março de 2021, e a Sentença de 23 de setembro de 2021 (cujo inteiro teor não havia sido publicado até o encerramento da presente pesquisa) ${ }^{16}$. Por seu turno, o caso brasileiro será lido com base nas decisões proferidas pelo STF na Arguição de Descumprimento de Preceito Fundamental (ADPF) n. 672,17 na Ação Direta de Inconstitucionalidade (ADI) n. $6.625^{18}$ e, com maior enfoque, na ADI n. 6.341. ${ }^{19}$

\section{Backsliding: a Covid-19 e o temor de um recuo democrático}

O backsliding democrático consiste em um recuo gradual na qualidade da democracia, que pode resultar na perda das qualidades democráticas do Estado e na sua transformação em regime iliberal ou regime autoritário (cf. MARTINELLI, 2017). Tal fenômeno se torna atualmente mais sensível pelo fato de que, hoje, a democracia não entra em colapso pela simples supressão do processo eleitoral, mas por formas muito mais sutis e complexas (Cf. LEVITSKY; ZIBLATT, 2018, p. 9-10).

\footnotetext{
15 Disponível em: https://www.cortecostituzionaactionSchedaPronuncia.do?param_ecli=ECLI:IT:COST:2021:4. Acesso em: 2 ago. 2021.

16 Comunicado disponível em: https://www.cortecostituzionale.it/documenti/comunicatistampa/CC_ CS_20210923171900.pdf. Acesso em: 27 set. 2021.

17 Decisão de concessão parcial de medida cautelar (STF, ADPF 672 MC, Decisão Monocrática, Rel. Min. Alexandre de Moraes, j. 8 abr. 2020), e decisão do Plenário que referendou tal medida cautelar e, no mérito, julgou parcialmente procedente a ação de controle concentrado (STF, ADPF 672 MC-Ref, Tribunal Pleno, Rel. Min. Alexandre de Moraes, j. 13 out. 2020).

${ }^{18}$ Decisão de concessão parcial de medida cautelar (STF, ADI 6625 MC, Decisão Monocrática, Rel. Min. Ricardo Lewandowski, j. 30 dez. 2020), e decisão do Plenário que referendou tal medida cautelar (STF, ADI 6625 MC-Ref, Tribunal Pleno, Rel. Min. Ricardo Lewandowski, j. 8 mar. 2021).

${ }^{19}$ Decisão de concessão parcial de medida cautelar (STF, ADI 6341 MC, Decisão Monocrática, Rel. Min. Marco Aurélio, j. 24 mar. 2020), e decisão do Plenário que referendou tal medida cautelar (STF, ADI 6341 MC-Ref, Tribunal Pleno, Rel. Min. Marco Aurélio, Rel. p/acórdão Min. Edson Fachin, j. 15 abr. 2020).
} 
Com efeito, o século XX foi marcado pela ascensão de regimes totalitários ou autoritários, e a democracia só se tornou o regime predominante em escala internacional no final do referido século. Segundo Barberis, até 1970 o mundo contava somente com 35 democracias eleitorais, ou seja, em que os governantes eram eleitos pelo povo. Com a globalização e a queda do mundo de Berlim, o total dessas democracias saltou para 120 a partir dos anos 2000 (BARBERIS, 2020, p. 96-97). Entretanto, desde 2015 tem-se iniciado uma onda de backslidings democráticos que, curiosamente, não quer dizer uma diminuição das democracias eleitorais então existentes (cf. BARBERIS, 2020, p. 96-97). Pelo contrário, os governantes continuam a ser eleitos pelo povo em quase qualquer lugar; se, no passado, o recuo democrático pressupunha tomadas arbitrárias de poder ou golpes de Estado, hoje este fenômeno faz uso do processo eleitoral para parecer mais legítimo.

Por outro lado, a concentração do poder no Executivo e o enfraquecimento dos mecanismos de controle políticos, técnicos ou jurisdicionais sobre o governo indicam quando uma democracia se transforma estruturalmente em populismo.

O quadro de incerteza jurídica sobre a pandemia da Covid-19 oferece talvez um risco de backsliding democrático dentro dos sistemas jurídicos da Itália e do Brasil por meio de excesso ou deficiência de ação governamental. Tal quer dizer, por um lado, que a construção de uma normativa própria para disciplina da emergência sanitária abre a chance de concentração de poder político nas mãos de um único governante (DRESDEN; HOWARD, 2016, p. 1136), o que pode afetar não só o equilíbrio entre poderes, senão também o razoável exercício dos direitos de liberdade. Assim tem sido o caso do excesso de edição de decretos administrativos - em detrimento de leis ordinárias emanadas pelo Parlamento, conforme orienta as bases da democracia liberal (cf. BARBERIS, 2020, p. 31) - para disciplinar juridicamente a realidade. Por outro lado, a deficiência de medidas preventivas e de contingência em relação aos avanços da crise sanitária pode sinalizar que os governos não garantem direitos mínimos como a vida, a saúde e a dignidade socioeconômica das pessoas, que certamente são direitos humanos em relação aos quais nenhuma negligência por parte do Estado é admissível.

Lembre-se, por oportuno, que as atuais Constituições italiana (1947) e brasileira (1988) foram precedidas por ditaduras, respectivamente, a fascista (1925-1943) e a militar (1964-1985). Embora não coincidam cronologicamente e constituam tipos juridicamente distintos de regimes de exceção, ambas são semelhantes em pelo menos dois aspectos: a prática de atos arbitrários 
do governo contra a sua própria população (não se falava em rule of law) e a ausência de instituições contramajoritárias capazes de, efetivamente, deter o avanço do autoritarismo.

Nesse sentido, no caso da Itália, a ordem jurídica era dominada pela orientação política e hegemonia cultural do governo fascista (1925-1943). Na prática, o Poder Executivo detinha ampla margem de discricionariedade para exercer não só funções de governo, mas também funções legislativas - por meio de decretti-legge - quando havia "emergência" ou "necessidade". Tal poder político não era sequer limitado pela Constituição (Estatuto Albertino), que era dotada de um caráter meramente flexível e pouco normativo (DELPÉRÉE, 1988, p. 99).

No caso do Brasil, por sua vez, a ditadura militar também foi notabilizada por atribuir a atos administrativos emitidos pelo governo uma hierarquia jurídica superior aos direitos e garantias previstos na Constituição. A esse respeito, vale destacar o conhecido Ato Institucional no 5, de 13 de dezembro de 1968 (AI-5), utilizado para fortalecer a repressão contra a dissidência, suprimir os direitos civis e perseguir os opositores.

Diante desse contexto, a vigência atual do constitucionalismo liberal tanto na Itália quanto no Brasil pretendeu contrabalancear, de alguma forma, o passado iliberal vivido pelos dois países. Para tanto, foi apresentada uma lista de instituições com diferentes perfis (político, técnico ou jurisdicional) com o objetivo de "desbloquear gradualmente a democracia" de seu passado totalitário (caso italiano) ou autoritário (caso brasileiro).

Entretanto, o estado de emergência sanitária em razão da Covid-19 levou os governos de ambas as nações a se socorrerem, mais uma vez, pela alta quantidade de atos normativos - medidas provisórias e atos administrativos - emanados pelo Poder Executivo para conter as imprevisões e efeitos jurídicos da pandemia. ${ }^{20}$ Com isso, foi soado o alerta do risco de que os atos governamentais como fontes autônomas pudessem ser usados não apenas para desafiar a pandemia, mas o próprio constitucionalismo em termos gerais. Afinal, tais atos poderiam

\footnotetext{
20 A este respeito, vale ressaltar que a Comissão Europeia destacou em seu Relatório sobre a Rule of Law 2020 que o governo italiano recorreu a medidas provisórias e medidas regulatórias para enfrentar a pandemia da Covid-19. Embora a Comissão Europeia não tenha feito nenhuma recomendação contra a disciplina regulatória excessiva adotada pelo governo, o registro desta situação em um relatório tão importante mostra que o órgão da União Europeia tem acompanhado o assunto de perto (cf. EUROPEAN COMMISSION, 2020, p. 16-17).
} 
prejudicar o equilíbrio entre os poderes já durante o estado de necessidade ${ }^{21}$, e tal efeito prejudicial sobre o Estado de direito poderia persistir no futuro. Em sentido inverso, a omissão de medidas efetivas pelo governo contra a pandemia poderia significar a ausência da garantia mínima dos direitos individuais, sociais e coletivos implicados; ademais, a ausência de uma disciplina legislativa apropriada não poderia servir de obstáculo para que o Estado oferecesse uma pronta resposta à crise sanitária, especialmente à luz dos reflexos que ela tem espelhado em todo o mundo, com milhões de mortes e prejuízos econômicos incalculáveis.

Como se verá mais adiante, especialmente no início da pandemia houve alguma relutância dos Parlamentos da Itália e do Brasil em realizar uma fiscalização mais atenta a todas as medidas tomadas pelo Poder Executivo e em adotar disciplinas legislativas que pudessem servir de legitimação às ações de contingência e da gestão pandêmicas. Devido a esse fato, os Tribunais Constitucionais de ambos os países emitiram julgamentos de cautelar ou de mérito a fim de moderar o equilíbrio entre os poderes, seja em sentido horizontal (salvaguardando as esferas de competência do Parlamento e do Governo) ou em sentido vertical (salvaguardando o modelo federal ou regional seguido pelo país). ${ }^{22}$

A posição tanto da Corte Constitucional italiana quanto da Suprema Corte brasileira foi importante para evitar a ameaça de concentração excessiva do poder político nas mãos de um único centro de poder ou a inércia na proteção dos interesses da sociedade afetados pela crise sanitária.

\section{Experiência da Itália: direção unitária da crise e presença de contrapoder político}

A partir dos primeiros surtos do novo coronavírus na Itália, no início de 2020, o Parlamento do país sofreu uma forte redução das suas atividades típicas (fiscalizatória e legislativa), denotando, de certa forma, uma renúncia à posição de centralidade que tal órgão sempre exerceu dentro da República parlamentarista italiana (PERTICI, 2020, p. 10).

\footnotetext{
${ }^{21}$ Acerca da legitimidade dos atos emanados por governos para contar os problemas decorrentes do estado de necessidade da pandemia, Azzariti sustenta que não se pode negar que a necessidade de facto se eleva a uma fonte autônoma quando as medidas são indispensáveis para satisfazer necessidades súbitas e imprevisíveis que põem em questão a própria existência do Estado e da comunidade de referência, não se deve aceitar que, uma vez terminado o estado de necessidade, a violação das regras continue (cf. AZZARITI, 2020).

22 Vide as decisões mencionadas no item 2 do presente artigo científico.
} 
A escassa presença do Parlamento durante o primeiro momento da pandemia deveu-se às dificuldades encontradas para reunir os seus membros em modalidade presencial, ante os riscos de contágio da Covid-19. Além disso, tanto a Câmara como o Senado resistiram em promover deliberações na modalidade à distância, em razão de questões de segurança e, principalmente, pelo receio da baixa qualidade democrática que esse tipo de deliberação poderia oferecer ao país (PERTICI, 2020, p. 9-13).

Por outro lado, o governo central italiano manifestou maior capacidade de agir prontamente em face do problema, liderando a edição de regulações normativas à crise por meio de Medidas Provisórias, Decretos Administrativos e outros atos regulamentares. Entretanto, o governo central encontrou dificuldades para lidar com os interesses e peculiaridades manifestadas pelos governos regionais e locais (PERTICI, 2020, p. 6-9).

De fato, um dos fatores mais problemáticos para a crise pandêmica na Itália foi de natureza político-constitucional, qual seja, a incapacidade dos diferentes níveis de governo (central, regional e local) de seguir uma distribuição equilibrada de poder para a tutela da saúde, dada a reduzida presença do Parlamento na normatização da gestão pandêmica.

Nesse ponto, vale ainda considerar como a Constituição italiana de 1947 disciplina as competências dos entes subnacionais no que respeita à pandemia: se, por um lado, a profilaxia internacional é assunto de competência exclusiva do Estado (art. 117, $\$ 2^{\circ}, q^{23}$ ), por outro, a tutela da saúde é tanto de competência legislativa concorrente (art. 117, $\$ 3^{0^{24}}$ ) quanto de competência administrativa comum, devido à sua essencialidade para a vida humana $\left(\$ 5^{025}\right)$.

Esse quadro poderia ter implicado uma união de esforços de todas as esferas subnacionais logo que a pandemia começou a se propagar, mas as incertezas sobre a melhor maneira de aplicar esse marco normativo constitucional fez com que o governo central - a partir de Roma - não conseguisse conter eficazmente

\footnotetext{
23 Verbis: "O Estado tem legislação exclusiva nos seguintes assuntos: (...) q) alfândegas, proteção das fronteiras e profilaxia internacional; (...)”.

24 Verbis: “São assuntos de legislação concorrente aqueles relativos a: (...); tutela da saúde; (...)”.

25 Verbis: "A República, una e indivisível, reconhece e promove as autonomias locais; atua a mais, ampla descentralização administrativa nos serviços que dependem do Estado; adequa os princípios e os métodos de sua legislação às exigências da autonomia e da descentralização".
} 
o agravamento do risco sanitário que surgia em nível mais periférico (a exemplo da dificuldade de conter o foco da Covid-19 que eclodiu localmente na região da Lombardia desde janeiro de 2020).

\subsection{Disfunções políticas da colaboração no regionalismo italiano}

No contexto italiano, duas foram as razões normativas que atrasaram uma combinação de governanças nacional e periféricas no combate da crise. A primeira é que a Constituição de 1947 é pouco clara ao identificar os limites de atuação tanto do Estado central quanto das Regiões no que tange às competências compartilhadas. Assim, cada qual dessas entidades subnacionais, a partir de sua projeção nacional ou regional, procura afirmar o alcance de suas competências, bem como provocar a Corte Constitucional ${ }^{26}$ em casos de conflitos legislativos entre o Estado central e a Região, ou entre as Regiões, se os interesses político-constitucionais do ente-competidor forem colocados em risco pelo ente-adversário (RUGGERI, 2020, p. 101).

Contudo, essa indefinição da ocupação dos entes autônomos no quadro de competências compartilhadas é mais evidente em tempos de crise, em que a sociedade precisa de um Estado que seja capaz de se reorganizar, rapidamente, entre seus diferentes centros de poder.

Já a segunda razão é que a Itália não possui nenhuma lei que regule efetivamente o "princípio da leal colaboração" entre entidades territoriais no contexto da atual pandemia. Em termos precisos, o Conselho dos Ministros decretou a emergência sanitária em sua reunião de 23 de janeiro de 2020 (publicada oficialmente em 31 de janeiro do mesmo ano), com base no Código de Proteção Civil italiano (Decreto-Legislativo n. 1, de 2/1/2018 ${ }^{27}$ ). No entanto, tal Código é adequado apenas para disciplinar eventos restritos a certas áreas do país, não servindo para eventos com proporções maiores, tais como a pandemia do novo coronavírus (CATELANI, 2020, p. 225-226) ${ }^{28}$. Assim, uma legislação específica

\footnotetext{
${ }^{26}$ Através do procedimento em via principal.

27 Trata-se de um ato com força de lei editado pelo governo central sob delegação de poder dada pelo Parlamento, nos termos do art. 76 da Constituição de 47.

28 Os artigos do Decreto-Legislativo 01/2018 utilizados para o decreto de emergência $\left(7, \S 1^{\circ}\right.$, c e $\left.24, \S 1^{\circ}\right)$ foram aplicados porque utilizam a fórmula genérica "eventos calamitosos de origem natural ou resultantes da atividade
} 
que correspondesse à dimensão e complexidade da presente situação sanitária deveria ter sido editada pelo Parlamento tão logo fosse possível, não apenas para definir o papel de cada ente subnacional em meio à pandemia, com clareza e precisão mínimas, senão também para facultar uma dinamização da gestão sanitária entre uma acepção mais ou menos centralizada, dependendo de como os efeitos sanitários mais graves se estenderiam pelo território nacional. Todavia, quase um ano depois da declaração da emergência sanitária na Itália, essa omissão do legislador ainda não havia sido removida (CATELANI, 2020, p. 225-226).

$\mathrm{Na}$ ausência de referências mais úteis da Constituição e do legislador, o poder normativo foi então exercido pelo governo central italiano (Consiglio dei Ministri) por meio da Medida Provisória (Decreto-Legge) n. 6, de 23 de fevereiro de 2020. No entanto, em vez de impulsionar a gestão subnacional, tal diploma estabeleceu uma centralização relevante na gestão sanitária, deixando às Regiões o papel de meras operadoras administrativas das decisões tomadas pelo Premier (Presidente del Consiglio dei Ministri), colocando em perigo "[...] a leal colaboração que sempre caracterizou o regionalismo italiano.” (CATELANI, 2020, p. 225-226).

Em resposta a um pedido dos governos regionais (Giunte Regionali) para receber mais atribuições na emergência sanitária, o Premier assinou nova Medida Provisória (n. 19, de 25 de março de 2020) concedendo às Regiões a atribuição de "introduzir outras medidas ulteriores restritivas, como as do art. $1^{\mathrm{o}}, \$ 2^{\mathrm{o} 29}$, exclusivamente no âmbito das atividades de sua competência e sem afetar as atividades produtivas ou as de relevância estratégica para a economia nacional" $\left(\right.$ art. $\left.3, \$ 1^{\circ}\right)$. Entretanto, o progresso trazido pela nova legislação não foi capaz de restaurar, pelo menos a priori, o espírito de leal colaboração no contexto do sistema de autonomia territorial da Itália, uma vez que, por um lado, não proporcionou nenhuma margem para que os prefeitos das cidades (Sindaci dei Comuni) também introduzissem outras medidas restritivas nas situações de piora do contexto local, e, por outro, estabeleceu uma espécie de delegação de competência normativa ao próprio Premier (e seu governo) para que pudesse regular a crise por meio de decretos administrativos (Decreti del Presidente del Consiglio dei Ministri) e instruções do Ministério da Saúde (Ordinanze Ministeriali), assegurando a possibilidade de adoção de medidas centrais, como fechamento de escolas e lockdowns sem a

\footnotetext{
humana”, embora não regulem emergências pandêmicas de nenhuma forma específica.

29 Dispõe sobre as medidas sanitárias que podem ser adotadas, como a limitação da circulação de pessoas, fechamento ao público de espaços públicos, proibição de se deslocar para outras cidades, proibição de reuniões, fechamento de estabelecidos comerciais etc.
} 
necessária participação dos outros governos subnacionais no processo decisório. Como resultado, a gestão da pandemia permaneceu formalmente verticalizada e mal distribuída na Itália (cf. CATELANI, 2020, p. 281).

Nesse contexto, os decretos administrativos do Premier passaram a ser desafiados por governos locais e regionais que resistiam a sujeitar-se de maneira tão verticalizada em meio à necessidade de agir contra os eventos da crise. Por exemplo, para conter a proliferação do novo coronavírus em Messina, cidade localizada na Região da Sicília, o Prefeito local baixou a Ordinanza n. 105, de 5 de abril de 2020, autorizando o acesso ao porto de Messina somente àqueles que cumprissem os seguintes requisitos: (1) agendamento on-line 48 horas antes da hora programada de partida em direção ao porto; (2) aguardar a emissão de autorização de entrada pelo governo local; (3) para quem pretendia sair da Sicília pelo porto de Messina, agendamento antes do embarque. Ocorre que tal decisão contrastava com as medidas nacionais estabelecidas pelo governo central, que apresentou um procedimento de anulação extraordinária contra a Ordinanza n. 105 perante o órgão de cúpula da justiça administrativa italiana, o Conselho de Estado, com base no art. 138 da Lei de Ordenamento dos entes locais. Para a doutrina, tal procedimento constituiu um tipo de verificação da legitimidade administrativa dos entes subnacionais no âmbito do regionalismo italiano com referência não só ao princípio da leal colaboração, mas também ao princípio da subsidiariedade,,$^{30}$ ambos previstos no art. 120, $\$ 1^{\circ}$, da Constituição de 1947 (PIGNATELLI, 2020, p. 574).

Em seu parecer obrigatório, expedido em 7 de abril de 2020, o Conselho de Estado considerou que o ato administrativo local em questão violava a proteção da unidade do ordenamento jurídico. Todavia, o item 8.5 do ato do Conselho serviu para que a justiça administrativa temperasse o poder normativo desempenhado pelo Estado central, ajudando a delimitar certos espaços de atuação aos governos subnacionais para agir em face da pandemia, a saber: (a) no caso

\footnotetext{
${ }^{30}$ A subsidiariedade é um princípio fornecido pelo sistema jurídico italiano para disciplinar a função administrativa (art. 118 da Constituição de 1947). De acordo com esse princípio, uma função administrativa é exercida preferencialmente pela menor entidade do sistema de autonomia territorial, ou seja, as cidades (Comuni). Entretanto, uma atribuição administrativa é transferida total ou parcialmente às Províncias, Regiões ou ao Estado central, dependendo da prevalência do interesse da matéria em discussão. Além disso, a Corte Constitucional italiana, nas suas Sentenças 303/2003 e 6/2004, já declarou que o princípio de subsidiariedade pode ser aplicado não só às funções administrativas, como ainda às funções legislativas. Isto é, para a Corte Constitucional, quando a função administrativa tem que ser exercida pelo Estado central por razões de unidade nacional, então também a função legislativa equivalente deve ser exercida pelo mesmo órgão, desde que tal seja fundamental para o exercício das mesmas funções administrativas, a fim de evitar disciplinas diferentes de Região para Região.
} 
de mora na adoção de decretos administrativos pelo Premier; (b) em relação às situações específicas de agravamento do risco em seu território ou em parte dele, devidamente demonstradas; $(c)$ exclusivamente dentro das atividades de competência de cada ente subnacional; e $(d)$ sem afetar as atividades produtivas e as de importância estratégica para a economia nacional (ITALIA, 2020).

À luz desse precedente, não se pode dizer que o papel de protagonismo do Premier no poder normativo da pandemia esteja causando um total desequilíbrio na relação entre as entidades subnacionais da Itália, pois, na prática, há alguma margem para que as entidades menores (Giunte Regionali e Comuni) produzam normas de execução difusas para contingenciar o novo coronavírus, de acordo com os seus respectivos critérios contextuais.

\subsection{Falta de standards parlamentares, emprego de standards científicos}

À luz do que se acaba de expor, tem-se que, mesmo assim, a ausência do Parlamento na disciplina normativa é sentida, v.g., quando os critérios de saúde adotados pelos entes subnacionais em relação à implementação de medidas protetivas não convergem entre si ante a inexistência de standards de cooperação sanitária. Isso abre espaço não só para o governo central se impor pela força, ignorando as opiniões provenientes dos outros níveis de governo, senão também para alguns "Governadores" de Regiões procederem de maneira semelhante, editando os seus próprios atos administrativos mais para desafiar o poder nacional do que para servir à sua população em geral (cf. DOMANI, 2020). Nesse último caso, vale destacar o evento em que a Região da Campânia, após o aumento de infecções, ordenou subitamente a suspensão de todas as atividades escolares sem ouvir a posição técnica do governo central sobre o tema, o que indicava que restringir as atividades educacionais desse modo significaria que cientificamente não faria nada para resolver a situação da infecção, prejudicando, ainda, o ano letivo dos estudantes (cf. CAMPANIA, 2020).

Outro motivo pelo qual a emergência da Covid-19 exige do Parlamento italiano uma liderança maior em comparação com aquela desempenhada pelo Premier é que hoje "os procedimentos emergenciais estão disponíveis a partir de maiorias políticas ocasionais” (cf. PALERMO, 2020). Tal é evidente a partir de duas práticas normativas comuns em tempos de pandemia na Itália. A primeira é a da edição de Medidas Provisórias (MP), que, embora sujeitas à conversão em lei 
ordinária, com a aprovação da maioria simples da Câmara e do Senado (art. 77, $\$ 2^{\circ}$, Constituição de $1947^{31}$ ), são, na prática, quase sempre aprovadas, pois, no parlamentarismo italiano, o Premier deve ter uma maioria simples em cada Casa legislativa para poder governar. Dessa forma, a mesma maioria que sustenta o governo acaba por assegurar a aprovação de todas as suas Medidas Provisórias. A segunda, a seu turno, é o ato de decretação do estado de emergência sanitária, estabelecido por um ato simples do Conselho de Ministros, contrastando com o que ocorre em países como o Brasil, em que o estado de calamidade pública é aprovado pelo Congresso Nacional, e também na Alemanha e na Espanha, onde o Parlamento não só assume a estratégia da emergência, mas também decide sobre a sua justa ordenação por meio de um quórum de aprovação bem mais consolidado e estável, isto é, de maioria absoluta ou qualificada (PALERMO, 2020).

Entretanto, embora a normatização autoproduzida pelo Premier crie dificuldades na partilha de medidas sanitárias executivas, certo é que também produz resultados relevantes às medidas sanitárias de planejamento, devido à adoção, pelo governo central, de critérios científicos na prevenção e imunização da SARS-CoV-2. A esse respeito, é de notar que, em 14 de janeiro de 2021, em paralelo com a decisão de prolongar o estado de emergência no país até 30 de abril de 2021, o governo central editou a Medida Provisória n. 2, que, entre outras providências, estabeleceu um planejamento nacional de vacinação que seguiu as orientações do Piano strategico per la vaccinazione anti-SARS-CoV-2/ COVID-19, ${ }^{32}$ um documento científico elaborado pelo Ministério da Saúde em parceria com instituições como o Instituto Superior de Saúde, que é o principal centro de pesquisa, controle e consulta em matéria de saúde pública na Itália.

A mesma MP n. 2/2021 criou uma plataforma nacional informatizada para facilitar a distribuição em todo o país de doses de vacinas e insumos de apoio à sua administração (como seringas e agulhas), além do controle e rastreamento de todos esses materiais. Ademais, reconhece-se que tal Medida Provisória deu uma certa margem de apreciação às Regiões e Províncias Autônomas italianas no que concerne à alocação desses ativos, uma vez que podem inserir, dentro da plataforma nacional, dados e solicitações atinentes à realização de operações de reserva de vacinas, seu registro administrativo e sua certificação, que serão

\footnotetext{
31 Art. 77, $\$ 2^{\circ}$. Quando, em casos extraordinários, de necessidade e de urgência, o Governo adota, sob a sua responsabilidade, medidas provisórias com força de lei, deve no próprio dia apresentá-los para a conversão às Câmaras que, mesmo se dissolvidas, foram propositadamente convocadas, devendo reunir-se no prazo de cinco dias.

32 Disponível em: http://www.salute.gov.it/imgs/C_17_pubblicazioni_2986_allegato.pdf. Acesso em: 22 jan. 2021.
} 
transmitidos ao Ministério da Saúde. É verdade que o argumento científico não elimina os riscos de o Premier decidir unilateralmente e em desacordo com as instituições, uma vez que o governo central permanece como principal fonte de disciplina normativa da pandemia. Contudo, a ciência é um elemento de certeza, segurança e que reduz as chances de uma autoridade de gestão frustrar as expectativas democráticas.

\subsection{Resposta discreta da justiça constitucional}

No tocante à Corte Constitucional da Itália, importa salientar que a sua resposta foi discreta no que se refere aos desequilíbrios entre poderes na gestão da pandemia, seja em termos de quantidade de casos analisados ou à luz do conteúdo decisório. Para tanto, analisa-se o Caso do conflito de competência entre o Estado e a Região do Vale d'Aosta, enfrentado pela Ordinanza n. 4, de 14 de janeiro de 2021 e, posteriormente, pela Sentença n. 37 de $2021 .{ }^{33}$

Inicialmente, a Corte acolheu pedido cautelar feito pelo Premier para suspender os efeitos totais da Lei regional da Região do Valle d'Aosta n. 11, de 9 de dezembro de 2020, na medida em que criava uma espécie de gestão paralela da pandemia, inclusive com uma disciplina de medidas sanitárias menos rigorosa do que a decorrente da regulação levada a cabo pelo governo central. Como ressalvas, a Corte assinalou que a Lei regional (i) estava a invadir matéria relativa à profilaxia internacional, reservada à competência exclusiva do Estado central (art. 117, $\$ 2^{\circ}$, da Constituição), (ii) causava grave e irreparável risco à saúde das pessoas, por estabelecer medidas contra a difusão do contágio da Covid-19 mais brandas e menos eficazes, além do que (iii) comprometia a gestão unitária nacional da pandemia, a qual, todavia, não pode impedir uma diversificação regional no contexto da leal colaboração. É certo que tal posição poderia ser revista até o juízo de mérito, como salientado na própria Ordinanza, mas já era possível compreender, a partir dos argumentos utilizados, que a concessão da medida cautelar suspensiva pela Corte italiana era um sinal favorável ao modelo de gestão centralizada estabelecido.

Além disso, a Corte sublinhou que os entes subnacionais menores precisavam assumir alguma margem de decisão no tocante à operatividade das

${ }^{33}$ Corte Constituzionale, Sentenza n. 37/2021, pubblicazione in G. U. 17/03/2021. 
medidas sanitárias, de acordo com as peculiaridades regionais, não obstante esse ponto não ter sido esclarecido em termos práticos na decisão. Essa linha decisória ainda se sustentou por uma razão de contexto: a Corte entendeu que as medidas sanitárias disciplinadas pelo Premier observavam um rigor que correspondia à gravidade da pandemia, fato que, como se verá, contrasta com a experiência brasileira.

A medida cautelar foi confirmada pela Sentença n. 37, de 2021. ${ }^{34}$ Toda a fundamentação decisória seguiu coerentemente o mesmo tom, o que vale como um termômetro para outros casos envolvendo conflitos entre Estado e Região no âmbito da crise, dado que não é possível que a cadeia de regulação sanitária estabelecida pela Região se sobreponha àquela predefinida pela competência normativa do Estado central, sob pena de caracterizar invasão inadequada da legislação regional sobre a legislação nacional. A Corte também preferiu evitar a armadilha das questões transversais, de modo a não causar ambiguidade na crise. A coordenação da pandemia permaneceu, portanto, sob a responsabilidade do Estado central em nível nacional, com a possibilidade de integração complementar ou adicional pela legislação regional (CARAVITA, 2021, p. 3-4).

Por fim, de acordo com comunicado emitido em 23 de setembro de $2021^{35}$, a Corte Constitucional julgou infundada questão de inconstitucionalidade contra a MP n. 19/2020. Em síntese, tal diploma havia sido impugnado por atribuir ao próprio Premier o poder de prever infrações administrativas por violação às medidas sanitárias da Covid-19, através de decreto regulamentar. Argumentava-se que tal poder seria de natureza legislativa, não podendo ser delegado a autoridade administrativa, nos termos dos arts. 76, 77 e 78 da Constituição.

Porém, seguindo uma linha de self-restraint que valida o regime normativo criado pelo Estado-central para enfrentamento da pandemia, a Corte declarou que ao Premier não foi conferida nenhuma outra função além daquela de implementar a Medida Provisória, podendo, portanto, baixar atos regulamentares para dispor sobre infrações administrativas.

Isso posto, observa-se que o protagonismo do Premier sobre o Parlamento dificulta a colaboração entre os entes subnacionais relativamente à execução

\footnotetext{
${ }^{34}$ Corte Constituzionale, Sentenza n. 37/2021, pubblicazione in G. U. 17/03/2021.

${ }_{35}$ Disponível em: https://www.cortecostituzionale.it/documenti/comunicatistampa/CC_CS_20210923171900.pdf. Acesso em: 27 set. 2021.
} 
de medidas de proteção sanitária, para além de diminuir a estabilidade das bases normativas empregadas para contingenciar o agravamento da pandemia. Todavia, esse protagonismo de um único centro de governo não vem representando realmente um risco à acumulação de poder político na Itália, uma vez que o poder normativo naquele país também recebe, indiretamente, influência dos entes subnacionais menores, fato que serve para contrabalançar as ações do Estado central. Ademais, em relação às medidas de planejamento sanitário, a adoção de critérios científicos está auxiliando o governo central a adotar políticas nacionais e sistêmicas balanceadas, especialmente focadas na distribuição de bens e serviços fundamentais à tutela da saúde. Portanto, o que a experiência tem demonstrado é que a autonomia territorial na Itália vem resistindo a um cenário de total confusão normativa, não exigindo uma resposta maior da justiça constitucional.

\section{Experiência do Brasil: direção fragmentada da crise e dificuldade de contrapoder político}

assim como na Itália, no Brasil não se vê o Parlamento como protagonista na normatização da autonomia territorial no contexto da pandemia do novo coronavírus. Entretanto, a maior diferença entre as situações vividas por esses dois países é que, em solo italiano, o chefe do governo central está desempenhando esse papel. Já em solo brasileiro, contrariamente, a mesma tarefa está a recair sobre uma instituição estatal absolutamente inesperada: o Supremo Tribunal Federal.

A esse respeito, convém, inicialmente, enfatizar que o federalismo nacional não tem uma disciplina específica para assuntos de interesse comum, o que torna difícil para o país conter os avanços da crise de saúde a partir das suas esferas subnacionais de governo. Por que isso acontece na prática? Uma resposta viável é a apatia do texto constitucional ao definir a natureza cooperativa do modelo federal brasileiro. Nesse sentido, há que se compreender, primeiro, as disfunções políticas do federalismo de cooperação no Brasil para, depois, verificar como o STF tem lidado com essa questão. 


\subsection{Disfunções políticas do federalismo de cooperação brasileiro}

A Constituição Federal de 1988 versa o tema da cooperação federativa em seu art. 23, parágrafo único, que induz ser da competência do Congresso Nacional - na elaboração de leis complementares - fixar normas para a cooperação entre os organismos subnacionais (União, Estados-membros, Distrito Federal e Municípios), à luz do "equilíbrio do desenvolvimento e o bem-estar em âmbito nacional”. Ocorre que, não obstante a boa intenção do dispositivo de estimular o consenso cívico no seio do federalismo, o uso vago de expressões retóricas como "equilíbrio” e "bem-estar” - que apenas expressam ideias já inerentes a qualquer cooperação subnacional - revela, na verdade, uma regra constitucional de baixo objetivo. Por consequência, tal disciplina constitucional não impede que se imponha a lei do mais forte, ou seja, que a União centralize em si mesma o poder decisório relativamente às responsabilidades socioeconômicas do Poder Público, em detrimento de um maior incremento na relação político-administrativa intergovernamental. Assim, pode-se dizer que a falta de “instrumentos aptos à redefinição de papéis entre as unidades federadas” acaba levando o modelo federal brasileiro a uma forma de organização verticalizada próxima a um modelo unitário de Estado (BERCOVICI, 2008, p. 12).

No âmbito da pandemia, esse quadro de centralização na esfera da União foi, em princípio, observado não apenas em relação à competência comum em matéria de saúde pública (art. 23, II, da CF/1988), mas também no que tange à competência legislativa concorrente que lhe corresponde (art. 24, XII, da $\mathrm{CF}$ 1988). Nesse sentido, pouco depois de a Itália ter iniciado a sua emergência sanitária em 31 de janeiro de 2020, o Congresso Nacional brasileiro mostrou, à primeira vista, interesse em regular a distribuição de tarefas entre os entes da federação, disciplinando as medidas para enfrentamento do coronavírus no Brasil, por meio da Lei n. 13.979, de 6 de fevereiro de 2020 ("Lei da Pandemia”). Tal lei surgiu, inclusive, antes do reconhecimento do estado de calamidade pública pelo mesmo Congresso Nacional, aprovado pelo Decreto Legislativo n. 6, de 20 de março de 2020, o qual, embora nascido para fins exclusivamente fiscais, passou também a ter efeitos na organização do Estado equivalentes aos resultantes do decreto de emergência sanitária na Itália ${ }^{36}$. Sucede que a Lei da

\footnotetext{
${ }^{36}$ A Lei n. 13.979/2020 (Lei da Pandemia), de acordo com o seu art. 8º (redação original), vigoraria enquanto perdurasse "o estado de emergência internacional pelo coronavírus responsável pelo surto de 2019". Essa disposição foi, ulteriormente, modificada para prever que a Lei da Pandemia "vigorará enquanto estiver vigente o Decreto
} 
Pandemia apresentava, desde a sua origem, um equívoco bastante evidente no que diz respeito às autonomias territoriais, pois deu à União autoridade quase exclusiva para decidir sobre as medidas sanitárias a impor no país, a exemplo do que fez no seu art. $3^{\circ}, \$ 7^{\circ}$, pelo qual o isolamento social e as medidas de quarentena só poderiam ser decretados pelo Ministro da Saúde ou por pessoa por ele autorizada, reservando, assim, aos governos estaduais e municipais um papel meramente secundário ou de portador de ordens.

Essa completa prevalência da União em detrimento das outras entidades subnacionais ficou ainda mais evidente com a edição, pelo Presidente da República, da Medida Provisória n. 926, de 20 de março de 2020, que, entre outras disposições, introduziu o $\$ 9^{\circ}$ ao art. $3^{\circ}$ da Lei da Pandemia, estabelecendo que só o próprio Presidente poderia decidir sobre o funcionamento dos "serviços públicos e atividades essenciais" em território nacional, não deixando qualquer margem aos Estados-membros para suplementar a matéria pela sua própria legislação ante situações particulares ocorridas no âmbito de sua abrangência, segundo versa o $\$ 2^{\circ}$ do art. 24 da Constituição Federal. ${ }^{37}$ Especificamente, essa iniciativa procurou verticalizar ainda mais o federalismo e centralizar o poder decisório nas mãos do Presidente da República.

Entretanto, em um movimento contracorrente semelhante ao ocorrido na Itália, os governadores e prefeitos brasileiros começaram a adotar, por conta própria, medidas restritivas para contingenciar a crise sanitária em curso, relativizando o papel secundário que a Lei da Pandemia lhes conferia. A postura desafiadora de tais gestores veio em meio ao fato de o Presidente da República expressar indiferença com relação aos impactos pandêmicos sobre a realidade brasileira, desde o advento da pandemia, bem como a intenção de administrar a

Legislativo n 6 , de 20 de março de 2020", o qual, por sua vez, reconheceu "a ocorrência de estado calamidade pública, com efeitos até 31 de dezembro de 2020, nos termos da solicitação do Presidente da República” (art. 1 do DL).

A seu turno, é importante dizer que o Min. Ricardo Lewandowski proferiu decisão monocrática concedendo parcialmente MC na ADI n. 6625 neste sentido: a vigência da Lei da Pandemia, de forma tecnicamente imperfeita, foi vinculada àquela do Decreto Legislativo n. 6/2020, que, reitera-se, decretou a calamidade pública para fins fiscais e somente até 31 de dezembro de 2020. No entanto, a caducidade temporal do mencionado Decreto Legislativo não poderia revogar os dispositivos da Lei da Pandemia que cuidam efetivamente de disposições de trato médico e sanitário (arts. $3^{\circ}$ ao $3^{\circ}-\mathrm{J}$ ). Isso porque, segundo o Min. Lewandowski, a real intenção do legislador, ao associar a Lei da Pandemia ao estado de calamidade pública, era manter as extraordinárias medidas profilácticas e terapêuticas pelo tempo necessário para superar a fase mais crucial da pandemia, mesmo porque nem o próprio legislador esperava a surpreendente persistência e letalidade da doença, como ainda se vê no tempo presente. Tal posição foi inteiramente referendada pelo Tribunal Pleno do STF em sessão virtual.

37 Verbis: "A competência da União para legislar sobre normas gerais não exclui a competência suplementar dos Estados". 
crise sanitária com laissez-faire excessivo, em desacordo com as recomendações e deliberações da Organização Mundial de Saúde.

Tal cenário levou o Supremo Tribunal Federal a se manifestar diversas vezes sobre a gestão da pandemia até o momento ${ }^{38}$. Nesse contexto, destaque-se o referendo dado pelo Plenário, em 15 de abril de 2020, à medida cautelar deferida pelo Min. Marco Aurélio na ADI n. $6.341 .{ }^{39}$ Nessa decisão plenária, o STF acolheu a posição do Min. Edson Fachin no sentido de dar ao $\$ 9^{\circ}$ do art. $3^{\circ}$ da Lei da Pandemia (acrescido pela MP n. 926/202040) interpretação conforme o art. 198, I, da Constituição de $1988^{41}$ para estabelecer o seguinte: a atribuição do Presidente da República para dispor sobre os serviços públicos e as atividades essenciais não exclui a atribuição de cada esfera subnacional de governo para agir em matéria de saúde pública no limite da sua "própria espacialidade jurídica e constitucional".

Na ocasião, salientou o Min. Edson Fachin que "[a] diretriz constitucional da hierarquização, que está no caput do art. 198 da Constituição, não significou e nem significa hierarquia entre os entes federados, mas um comando único dentro de cada uma dessas esferas respectivas de governo". Desse modo, sobre a competência concorrente em matéria de saúde no contexto da pandemia, o mesmo Ministro sublinhou que "se é certo que a União pode legislar sobre o tema, [...] o exercício dessa competência deve ser para resguardar a autonomia dos demais entes". Ademais, o julgamento assumiu a tônica de garantir o equilíbrio

\footnotetext{
${ }^{38}$ Como assinalado pelo Min. Ricardo Lewandowski, na MC na ADI n. 6.625, de 30 de dezembro de 2020: "O Supremo Tribunal Federal, em diversas decisões prolatadas ao longo do corrente ano, entendeu que tais medidas [protetivas sanitárias] são compatíveis com a Constituição, podendo ser adotadas pelas autoridades dos três níveis políticoadministrativos da Federação, respeitadas as esferas de competência que lhes são próprias (ADI 6.341-MC-Ref/DF, redator do acórdão Min. Edson Fachin; ADI 6.343-MC-Ref/DF, redator do acórdão Min. Alexandre de Moraes; ADPF n. 672/DF, Rel. Min. Alexandre de Moraes; e ADIs 6.362/DF, 6.587/DF e 6.586/DF, de minha relatoria), sendo certo que estas corresponderam plenamente às expectativas, revelando-se essenciais ao enfrentamento da Covid-19" (STF, ADI 6625 MC, Rel. Min. Ricardo Lewandowski, j. 30 dez. 2020).

39 STF, ADI 6341 MC-Ref, Tribunal Pleno, Rel. Min. Marco Aurélio, Rel. p/acórdão Min. Edson Fachin, j. 15 abr. 2020 .

40 Verbis: "O Presidente da República disporá, mediante decreto, sobre os serviços públicos e atividades essenciais a que se referem o $\$ 8^{\circ}$.

41 Verbis: "As ações e serviços públicos de saúde integram uma rede regionalizada e hierarquizada e constituem um sistema único, organizado de acordo com as seguintes diretrizes: I - descentralização, com direção única em cada esfera de governo".
} 
federativo em face da concentração de poder que o Presidente da República tentava atribuir a si mesmo por meio da Medida Provisória n. 926/2020. ${ }^{42}$

Desse modo, e também a partir do voto da Min. Rosa Weber, o julgamento da ADI n. $6.341 \mathrm{MC}$-Ref pelo STF definiu a seguinte regra de ouro sobre o equilíbrio federativo em relação às competências subnacionais: "Em casos de omissão da regulação devida ou de ausência de matéria que afete serviços públicos e atividades essenciais, subsiste, de modo pleno, a possibilidade de adoção de medidas à luz da autonomia federativa".

\subsection{Falta de gestão política orientada por standards políticos ou científicos e a necessidade de uma decisão manipulativa aditiva por parte do STF}

Na decisão da ADI n. 6.341 MC-Ref, a Corte Suprema, ao mesmo tempo em que adotou a técnica de interpretação conforme para extrair do texto da Lei da Pandemia o sentido de norma mais compatível com a Constituição (e o equilíbrio federativo) - tal como foi dito expressamente no acórdão citado -, adotou, a nosso ver, modelo decisório conhecido pela doutrina italiana como manipulativa aditiva. ${ }^{43}$

Com efeito, na prolação da referida medida cautelar, o STF suspendeu parcialmente a eficácia do disposto no $\$ 9^{\circ}$ do art. $3^{\circ}$ da Lei da Pandemia (incluído pela MP n. 926/2020), na parte em que restringia somente ao Presidente da República a atribuição para dispor sobre serviços e atividades essenciais no quadro da gestão pandêmica. Diante disso, com o fim de evitar o vazio legislativo que decorreria dessa cautelar suspensiva, o próprio STF acrescentou uma nova

\footnotetext{
${ }^{42}$ Vale observar esta passagem do voto da Min. Rosa Weber no âmbito da ADI n. 6.341 MC-Ref, verbis: "A possibilidade de o Presidente da República definir essas atividades, por decreto, a meu juízo, tangenciaria afronta ao princípio da separação de poderes (art. 2 ${ }^{\circ} \mathrm{CRFB}$ ). Isso porque há aqui uma instituição da figura do regulamento autorizativo, na medida em que o Presidente, por medida provisória, delegou poderes para si próprio, sem instituir critérios de controle e responsividade. Desse modo, o Congresso Nacional fica obstado a exercitar o controle do art. 49, V, da Constituição Federal, ante a ausência de parâmetros normativos de controle”. (STF, ADI 6341 MC-Ref, Tribunal Pleno, Rel. Min. Marco Aurélio, Rel. p/acórdão Min. Edson Fachin, j. 15 abr. 2020.).

43 Exemplos de decisões de manipulação aditiva no contexto da Corte Constitucional italiana são as Sentenças 190/1970, 63/1972 e 64/1972, enquanto, no contexto do STF, o caso mais conhecido é o julgamento ADPF n. 54 (caso do aborto de fetos anencefálicos). Sobre as espécies de sentenças manipulativas aditivas, Cf. BELLOCCI; GIOVANETTI, 2010, p. 15-18.
} 
norma para ocupar o lugar daquela cuja eficácia havia sido suspensa, especialmente visando a reger os casos pendentes ou futuros. ${ }^{44}$

Nesse sentido, o Supremo adicionou à disposição legislativa preexistente ( $\$ 9^{\circ}$ do art. $3^{\circ}$ ) um conteúdo normativo que estabeleceu a todas as instâncias governativas - e não apenas ao Presidente da República - a tarefa de dispor sobre serviços e atividades essenciais relativos à pandemia.

Em linhas gerais, o STF a esse respeito: (i) deixou de aplicar norma restritiva com fundamento na violação do princípio da isonomia ou paridade entre os entes federativos no que concerne à tutela da saúde; e (ii) produziu efeito aditivo ao distribuir as tarefas de gestão da pandemia, utilizando, analogicamente, a Lei do Sistema Único de Saúde (Lei n. 8.080/1990), criando - como diz a doutrina italiana - uma norma com "um escopo e conteúdo regulatório diferente daquele previsto originalmente” (ROMBOLI; ROSSI, 2001, p. 531).

Esse efeito aditivo decorre do avanço interpretativo assinalado pelo Min. Edson Fachin, redator do acórdão da Medida Cautelar na ADI n. 6.341/202045, para quem "[é] preciso ler as normas que integram a Lei n. 13.979, de 2020, como decorrendo da competência própria da União para legislar sobre vigilância epidemiológica, nos termos da Lei Geral do SUS, Lei n. 8.080, de 1990". A partir dessa percepção, o STF estabeleceu que a coordenação entre os entes federativos para atuar contra a crise pandêmica deveria seguir o mesmo processo de planejamento do SUS, que é "[...] ascendente, do nível local até o federal [...]" (art. 36, SUS). Por conseguinte, à direção nacional da pandemia, a cargo do Presidente da República, caberia definir e coordenar o sistema da emergência (art. 16, SUS); à direção estadual da pandemia, a cargo dos Governadores, restaria "coordenar e, em caráter complementar, executar ações e serviços" relacionados (art. 17, SUS); e à direção municipal recairia a atribuição primária de "executar serviços" (art. 18, SUS).

Sobre os resultados práticos da decisão, se, por um lado, impediu que o Presidente da República brasileiro acumulasse em si o poder normativo da

\footnotetext{
${ }^{44}$ Com as sentenças aditivas, a Corte Constitucional italiana declara ilegitimidade de uma determinada disposição "na parte em que não prevê algo", acrescentando parte nova ao texto legislativo originário. Para Zagrebelsky, essa função manipulativa ou reconstrutiva, que se propõe a evitar vazios legislativos, nasce em razão do caráter incidental da justiça constitucional italiana (Cf. ZAGREBELSKY, 2012, p. 610-611).

45 STF, ADI 6341 MC-Ref, Tribunal Pleno, Rel. Min. Marco Aurélio, Rel. p/acórdão Min. Edson Fachin, j. 15 abr. 2020 .
} 
pandemia, tal como semelhantemente fez o Premier no contexto italiano, por outro, produziu complexidade à coordenação dos entes federados ao decidir pela adoção da Lei do SUS como paradigma de planejamento em face da emergência do novo coronavírus. Ora, o citado diploma normativo foi criado para tempos de normalidade e não para uma pandemia como a da Covid-19, como se pode depreender nitidamente de seu conteúdo.

Aliás, nem é possível alegar que o art. 16, parágrafo único, da Lei do SUS ${ }^{46}$ se adequa às peculiaridades da pandemia, pois, embora essa regra traga expressões como "agravos inusitados à saúde" que "representem risco de disseminação nacional”, sua imprecisão de conteúdo torna difícil o seu emprego efetivo na atual crise. Por exemplo, a sua redação em nada esclarece - nem existe outra disposição na mesma Lei responsável por tal mister - como deve ocorrer a coordenação entre as tarefas desempenhadas por todas as entidades subnacionais em relação à crise sanitária. Em vez disso, o silêncio do parágrafo único do art. 16 a esse respeito não auxilia a atual emergência da Covid-19 no Brasil a superar o seu principal obstáculo: a ausência de standards mínimos de proteção sanitária que possam ser observados por todos os entes federativos na gestão sanitária da pandemia. Do contrário, a decisão do STF de que todos os entes federativos podem agir dentro dos limites da sua "espacialidade jurídica e constitucional”, no lugar de dinamismo e eficiência, pode converter-se em confusão federativa. A título de referência, na ausência de uma estratégia nacional de vacinação para o país, o Estado de São Paulo liderou políticas relacionadas com a produção e distribuição de doses de vacina (Coronavac), embora essa questão, por exigir uma gestão unitária e nacional, devesse ser gerida pela União.

Por fim, por meio da Lei n. 14.035, de 11 de agosto de 2020, o Congresso Nacional brasileiro substituiu a redação original do $\$ 9^{\circ}$ do art. $3^{\circ}$ da Lei da Pandemia pela seguinte:

"A adoção das medidas previstas neste artigo [medidas sanitárias] deverá resguardar o abastecimento de produtos e o exercício e o funcionamento de serviços públicos e de atividades essenciais, assim definidos em decreto da respectiva autoridade federativa."

\footnotetext{
46 Verbis: “A União poderá executar ações de vigilância epidemiológica e sanitária em circunstâncias especiais, como na ocorrência de agravos inusitados à saúde, que possam escapar do controle da direção estadual do Sistema Único de Saúde (SUS) ou que representem risco de disseminação nacional”.
} 
Contudo, verifica-se que, com essa reforma, o legislador limitou-se a reproduzir a ideia de "equilíbrio federativo" contida na Medida Cautelar na ADI n. $6.341^{47}$, sem ter-se dado ao trabalho de avançar, ou seja, de implementar uma regra mais clara destinada a facilitar a convergência entre o planejamento nacional e as execuções de medidas sanitárias.

\subsection{Resposta proativa da justiça constitucional}

Considerando as dificuldades de construir um planejamento federativo especificamente voltado para o contexto político da pandemia, um trabalho dessa envergadura deveria ter sido construído pelo Parlamento e não por uma Corte Suprema. No entanto, sem uma grande resposta do Congresso Nacional brasileiro a esse respeito, a decisão do STF foi fundamental para salvaguardar o equilíbrio subnacional, evolvendo todas as autonomias territoriais na busca por respostas à pandemia.

Nesse ponto, vale destacar o seguinte trecho do acórdão da Medida Cautelar na ADPF n. $672^{48}$, de 13 de outubro de 2020, relatado pelo Min. Alexandre de Moraes:

O Poder Executivo federal exerce o papel de ente central no planejamento e coordenação das ações governamentais em prol da saúde pública, mas nem por isso pode afastar, unilateralmente, as decisões dos governos estaduais, distrital e municipais que, no exercício de suas competências constitucionais, adotem medidas sanitárias previstas na Lei 13.979/2020 no âmbito de seus respectivos territórios, [...].

Apesar disso, o obstáculo à convergência entre o planeamento e a execução com relação à crise sanitária permanece evidente na realidade do país, especialmente devido à grande chance de que as ações de governança adotadas pela União, Estados, Distrito Federal e Municípios se sobreponham de alguma forma, fato que pode reduzir a eficiência sistêmica da gestão em curso. Vale ainda salientar que o papel do STF, embora bastante intenso, foi útil para atenuar a centralidade

\footnotetext{
47 STF, ADI 6341 MC-Ref, Tribunal Pleno, Rel. Min. Marco Aurélio, Rel. p/acórdão Min. Edson Fachin, j. 15 abr. 2020.

${ }^{48}$ STF, ADPF 672 MC-Ref, Tribunal Pleno, Rel. Min. Alexandre de Moraes, j. 13 out. 2020.
} 
da gestão da pandemia no governo federal, sem retirar a posição deste último como coordenador nacional do sistema da emergência do novo coronavírus e executor das ações mais estruturais diante da crise sanitária. Embora os termos da medida cautelar na ADI n. 6.341/2020 fossem muito esclarecedores nesse ponto, a resistência do Presidente da República em tomar uma posição ativa de articulação do planejamento federativo (e não meramente federal) para combater a pandemia levou o STF a negar publicamente que sua decisão tinha proibido o governo federal de agir na crise sanitária. É uma amostra que, de fato, a regulação da emergência da Covid-19 no Brasil ainda carece de um maior enquadramento político e não apenas jurídico. ${ }^{49}$

\section{Variação entre níveis de resposta dos tribunais constitucionais: uma salvaguarda para a rule of law}

A fim de inter-relacionar as experiências dos Tribunais Constitucionais da Itália e do Brasil com relação à pandemia da Covid-19, vale a pena, hipoteticamente, inverter os contextos políticos enfrentados por cada um dos países para discutir como as Cortes (Supremas ou) Constitucionais responderiam a situações completamente distintas. Em primeiro lugar, se as defesas majoritárias existentes na Itália se provassem menos efetivas para conter a atuação no governo italiano durante a pandemia, a Corte Constitucional responderia a eventuais riscos de violação à rule of law com maior proatividade? A princípio, uma vez que a justiça constitucional italiana foi construída sob forte influência do modelo kelseniano de Tribunal Constitucional, sua atuação reserva-se mais a um comportamento de legislador negativo que de uma Corte com maior âmbito de intervenção política, tal difere do que ocorre no modelo americano de justiça constitucional ou em modelos híbridos, como o brasileiro.

Por outro lado, a doutrina constitucional vem observando que, nos últimos anos, a Corte Constitucional italiana tem produzido, por meio da sua própria jurisprudência ou dos seus próprios regulamentos, uma espécie de agregação

\footnotetext{
49 Verbis: "A Secretaria de Comunicação Social do Supremo Tribunal Federal (STF) esclarece que não é verdadeira a afirmação que circula em redes sociais de que a Corte proibiu o governo federal de agir no enfrentamento da pandemia da Covid-19. Na verdade, o Plenário decidiu, no início da pandemia, em 2020, que União, estados, Distrito Federal e municípios têm competência concorrente na área da saúde pública para realizar ações de mitigação dos impactos do novo coronavírus. Esse entendimento foi reafirmado pelos ministros do STF em diversas ocasiões. Ou seja, conforme as decisões, é responsabilidade de todos os entes da federação adotarem medidas em benefício da população brasileira no que se refere à pandemia”. Disponível em: http://portal.stf.jus.br/noticias. Acesso em: 21 jan. 2021.
} 
de poder jurisdicional. Nesse sentido, é verdade que, a partir do advento da doutrina de Vezio Crisafulli ${ }^{50}$ denominada rimas obrigadas (rime obbligate), era possível justificar eventual decisão progressista dada pela Corte Constitucional italiana com base no argumento de que a Corte estava apenas cumprindo norma constitucional já existente. Entretanto, nos últimos dez anos e, especialmente, a partir de 2018, autores como Romboli (2020a, p. 9-11) e Tega (2020, p. 38-45) sublinham que o avanço criativo da justiça constitucional italiana vem confirmando um fenômeno de "superação das rimas obrigadas" (ROMBOLI, 2020b, p. 108) e consolidação da era dos "versos soltos" (TEGA, 2020, p. 38), isto é, na qual os juízes constitucionais desenvolvem suas decisões não só nas normas constitucionais escritas, mas também a partir do contexto. ${ }^{51}$

Esse panorama acende a possibilidade de a Corte Constitucional italiana gradualmente comportar-se menos como um legislador negativo e mais como um órgão de proteção democrática, construindo condições técnicas para discutir e decidir matérias que, até pouco tempo, ficavam reservadas ao órgão de representação política: o Parlamento.

Com relação à pandemia da Covid-19, o conteúdo da Sentença n. 37 de $2021^{52}$ representa uma atuação discreta, como já dito. No entanto, importa salientar que tal decisão ocorreu em sede do procedimento em via principal, voltado, a rigor, a decidir somente o conflito de competência legislativa entre EstadoRegião. Se, do ponto de vista jurídico, esse comportamento era esperado devido aos limites da justiça constitucional italiana quanto ao acesso à sua jurisdição - que não admite que as partes de um processo enviem diretamente a questão de constitucionalidade à Corte - e ao elenco de objetos de controle - que, a priori, está restrito à impugnação da legitimidade em tese de leis e atos normativos com força de lei -, certo é que, do ponto de vista político ou mesmo de proteção dos

\footnotetext{
50 Sobre a doutrina das rime obbligate, cf. CRISAFULLI, 1976.

${ }^{51}$ Como exemplo, vale destacar o Caso Cappato, no qual a Corte Constitucional criou um percurso procedimental em duas fases, completamente novo e jamais disciplinado pela ordem jurídica italiana. Primeiramente, diante de uma questão de inconstitucionalidade em relação ao crime do suicídio assistido, a Corte decidiu "não decidir": com a Ordinanza n. 207/2018, a Corte atribuiu ao Parlamento um prazo de onze meses para que corrigisse certa inconstitucionalidade - devidamente indicada na própria Ordinanza - e disse que só voltaria a analisar o caso após expirado o prazo fixado. Passados os onze meses sem que o legislador nada procedesse a respeito da correção legislativa, a Corte, então, decidiu analisar o caso no mérito. A Corte, assim, prolatou uma sentença por meio da qual disciplinou normativamente quando situações de suicídio assistido não constituiriam crime.

52 Corte Constituzionale, Sentenza n. 37/2021, pubblicazione in G. U. 17/03/2021.
} 
direitos humanos, o baixo risco de backsliding no contexto levou a Corte italiana a não exercer maior ativismo judicial.

Por sua vez, em relação ao caso brasileiro a pergunta que deve ser feita é inversa: se os mecanismos de contrapoder político estivessem mais coordenados, o STF responderia aos eventos da pandemia com mais discrição? Diferentemente do perfil kelseniano da Corte italiana, a Corte brasileira foi inspirada originalmente no perfil da Corte Suprema americana, que confere forte importância ao Poder Judiciário, como já sublinhava o Capítulo 78 de The Federalist, de Alexander Hamilton. Além do mais, o Brasil não segue um sistema de governo parlamentar, que atribui ao legislador maior autoridade para conter eventuais impulsos do Poder Executivo. Ao contrário, o Brasil é presidencialista e, por esse motivo, garante maior autonomia ao Governo para agir discricionariamente.

Diante desse cenário, entende-se que, ainda que instituições como o Parlamento e o federalismo estivessem atuando com maior ênfase no âmbito da pandemia, ainda assim o STF estaria também participando do debate político no Brasil, uma vez que o exercício da tripartição de poder entre nós é mais característico e vivo do que na realidade italiana - onde, vale citar: o Executivo é um Conselho eleito e mantido pela confiança da maioria parlamentar, enquanto a Corte Constitucional não é autorizada a realizar o controle de constitucionalidade combinando elementos de controles concreto e abstrato tal como realiza a Corte Suprema brasileira.

Apesar disso, é certamente possível considerar que quanto mais o exercício dos contrapoderes políticos amadurece no âmbito brasileiro, menos espaço o STF terá para justificar a prolação de sentenças proativas ou ativistas com base no contexto.

\section{Conclusão}

Ao cabo desta exposição foi possível compreender que as assimetrias atinentes ao funcionamento dos poderes horizontais e verticais de Estado no âmbito da pandemia na Itália e no Brasil tendem a contribuir para o surgimento de riscos à rule of law e, por consequência, de backsliding democrático. Tal significa que, quanto mais soluções as formas de governo e de Estado oferecerem para eventuais problemas decorrentes da gestão pandêmica, menor será a tendência ao ativismo ou à expansão do poder da justiça constitucional nos respectivos 
países. No entanto, cada vez que as assimetrias envolvendo instituições políticas e administrativas evidenciam desequilíbrios entre poderes, maior será o potencial da justiça constitucional em promover respostas proativas relativamente aos outros poderes do Estado.

Não obstante as peculiaridades institucionais que separam os Tribunais Constitucionais da Itália e do Brasil, é possível afirmar que tais Cortes vêm desenvolvendo, de algum modo, papéis que se baseiam também no contexto em que os juízes constitucionais estão situados. Dessa forma, levando em conta os riscos de backsliding democrático gerados pela pandemia da Covid-19, essas Cortes podem ser compreendidas como contrapoderes institucionais e não majoritários, que adaptam, transitoriamente, suas capacidades decisórias a depender do nível de excesso ou de deficiência política em relação à rule of law e, ainda, à tutela dos direitos.

Com relação às experiências da Corte Constitucional italiana e do Supremo Tribunal Federal brasileiro, verifica-se que a segunda Corte apresentou uma tendência maior de concentração ou expansão de poder jurisdicional no âmbito da pandemia. No entanto, tal fenômeno pode ser atribuído ao fato de que o Brasil talvez tenha apresentado maior risco de backsliding democrático relativamente ao contexto pandêmico.

\section{Referências}

AZZARITI, Gaerano. Il diritto costituzionale d'eccezione. Costituzionalismo.it, n. 1, 31 mar. 2020. Disponível em: https://www.costituzionalismo.it/wp-content/ uploads/0.-Fasc.1-2020.-Azzariti.pdf. Acesso em: 24 out. 2021.

BARBERIS, Mauro. Populismo digitale: come internet sta uccidendo la democrazia. Milano: Chiarelettere, 2020. 215 p.

BELLOCCI, Mario; GIOVANETTI, Tommaso. Il quadro delle tipologie decisorie nelle pronunce della Corte costituzionale. [Roma], 2010. Quaderno predisposto in occasione dell'Incontro di studio con la Corte costituzionale di Ungheria. Disponível em: https://www.cortecostituzionale.it/documenti/ convegni_seminari/STU\%20219_Tipologia_decisioni.pdf. Acesso em: 27 set. 2021. 
CAMPANIA: De Luca chiude le scuole, Conte non gradisce. Protesta degli scuolabus. I1 Sole 24 Ore, 15 out. 2020. Disponível em: https://www.ilsole24ore. com/art/campania-de-luca-chiude-scuole-fino-30-ottobre-solo-lezioni-distanzaazzolina-decisione-gravissima-ADIOULw. Acesso em: 2 ago. 2020.

CARAVITA, Beniamino. La sentenza della Corte sulla Valle d'Aosta: come un bisturi nel burro delle competenze (legislative) regionali. Federalismi.it: Rivista di Diritto Pubblico Italiano, Comparato, Europeo. Papr, 21 apr. 2021. Disponível em: https://www.segretaricomunalivighenzi.it/archivio/anno-2021/aprile/doccaravita.pdf. Acesso em: 24 out. 2021.

CARETTI, Paolo; DE SIERVO, Ugo, Dirit to costituzionale e pubblico. 3. ed. Torino: G. Giappichelli, 2017.

CATELANI, Elisabetta. Il rapporto fra stato e regioni al tempo del coronavirus: una premessa. Il Forum - L'emergenza e i rapporti tra lo Stato e le Regioni. La Rivista Gruppo di Pisa: Dibattito aperto sul Diritto e la Giustizia Costituzionale, n. 2, p. 275-302, 2020. Il Forum

L'emergenza e i rapporti tra lo stato e le regioni. Forum sull'emergenza, n. 2 Disponível em: https://www.gruppodipisa.it/images/rivista/pdf/Il_Forum_-_L_ emergenza_e_i_rapporti_tra_lo_Stato_e_le_Regioni.pdf. Acesso em: 24 out. 2021.

CRISAFULLI, Vezio. La Corte costituzionale ha vent'anni. Giurisprudenza costituzionale, n. 1, p. 1694-?, 1976.

DELPÉRÉE, Francis. Constitutional systems and sources of law. In: A. PIZZORUSSO (ed.), Law in the making: a comparative survey. Berlin: Springer, 1988. p. 88-102.

DRESDEN, Jennifer Raymond; HOWARD, Marc Morjé. Authoritarian backsliding and the concentration of political power. Democratization, v. 23, n. 7, p. 1122-1143, 2016.

EUROPEAN COMMISSION.2020 Rule of law report. [Bruxelas], 2020. Disponível em: https://ec.europa.eu/info/policies/justice-and-fundamental-rights/ upholding-rule-law/rule-law/rule-law-mechanism/2020-rule-law-report_en. Acesso em: 21 jun. 2021. 
ITALIA. Consiglio di Stato. Sezione Prima. Adunanza di Sezione del 7 aprile 2020, n. 735. Annullamento straordinario dell'ordinanza del Sindaco di Messina che obbliga chi intende attraversare lo stretto di Messina a registrarsi. Presidente: Maria Luigi Torsello. Estensore: Paolo Carpentieri. Disponível em: https://www.giustizia-amministrativa.it/web/guest/-/annullamentostraordinario-dell-ordinanza-del-sindaco-di-messina-che-obbliga-chi-intendeattraversare-lo-stretto-di-messina-a-registrarsi. Acesso em: 24 out. 2021.

LEVITSKY, Steven; ZIBLATT, Daniel. How democracies die. New York: Crown, 2018. 320 p.

LIPPOLIS, Vincenzo. Il rapporto parlamento - governo nel tempo della pandemia. Rivista AIC: Associazione Italiana dei Costituzionalisti, n. 1, 27 jan. 2021. Disponível em: https://www.rivistaaic.it/images/rivista/pdf/1_2021_8_Lippolis. pdf. Acesso em: 24 out. 2021.

MARTINELLI, Claudio. Brevi riflessioni sulla rule of law nella tradizione costituzionale del Regno Unito. Diritti Comparati, 5 giugno 2017. Post. Disponível em: https:/www.diritticomparati.it/brevi-riflessioni-sulla-rulelaw-nella-tradizione-costituzionale-del-regno-unito/. Acesso em: 21 jun. 2021.

MAZZUOLI, Valerio de Oliveira; FRAZÃO, Hugo Abas. Il federalismo come termometro costituzionale in tempi di crisi: un'analisi comparata alla luce dell'emergenza COVID-19 in Brasile e in Italia. La Rivista Gruppo di Pisa: Dibattito aperto sul Diritto e la Giustizia Costituzionale, Quaderno n. 1, Fascicolo Speciale Monografico, p. 97-110, 2020. Disponível em: https://www.gruppodipisa. it/images/rivista/pdf/Fascicolo_monografico_-_L_emergenza_sanitaria_da_ COVID-19_una_prospettiva_di_diritto_comparato.pdf. Acesso em: 24 out. 2021.

MAZZUOLI, Valerio de Oliveira; FRAZÃO, Hugo Abas. Lições ao constitucionalismo subnacional brasileiro e italiano a partir das normas de emergência no combate à Covid-19. In: THEODORO, Marcelo Antonio; SANTOS, Julia Natália Araújo (org.). Estudos avançados de direito constitucional em homenagem ao professor Carlos Antônio de Almeida Melo. Belo Horizonte: Letramento, 2021. v. 1.

PALERMO, Francesco. La pandemia delle fonti. Alto Adige, 28 out. 2020. Disponível em: https://palermofrancesco.wordpress.com/2020/10/28/ la-pandemia-delle-fonti/. Acesso em: 21 jun. 2021. 
PEGORARO, Lucio. A circulação, a recepção e a hibridação dos modelos de justiça constitucional. Revista de Informação Legislativa, Brasília , v. 42, n. 165, p. 59-76, jan./mar. 2005. Disponível em: https://www2.senado.leg.br/bdsf/bitstream/ handle/id/228/R165-07.pdf?sequence=4\&isAllowed=y. Acesso em: 24 out. 2021.

PERTICI, Andrea. Il potere politico di fronte all'emergenza: notazioni introduttive. La Rivista Gruppo di Pisa: Dibattito aperto sul Diritto e la Giustizia Costituzionale, n. 2, p. 321-363, 2020. Il Forum L'emergenza e i rapporti tra lo stato e le regioni. Forum sull'emergenza, n. 4. Disponível em: https://www. gruppodipisa.it/images/rivista/pdf/I1_Forum_-_Emergenza_Covid_e_organi_ costituzionali.pdf. Acesso em: 24 out. 2021.

PIGNATELLI, Nicola. Il potere di annullamento straordinario ex art. 138 TUEL di un'ordinanza comunale: il Covid-19 non "chiude" lo stretto di Messina. Diritti regionali - Rivista di diritto delle autonomie territoriali, n. 1, p. 567-580, 2020. Disponível em: https://www.dirittiregionali.it/wp-content/ uploads/2020/05/DIRREG2020-fascicolo.pdf. Acesso em: 24 out. 2021.

\section{ROMBOLI, Roberto (ed.). Aggionnamenti in tema di processo costituzionale (2017-2019). Torino: Giappichelli, 2020a. 416 p.}

ROMBOLI, Roberto. Il sistema di costituzionalità tra "momenti di accentramento" e "momenti di diffusione". La Rivista Gruppo di Pisa: Dibat tito aperto sul Diritto e la Giustizia Costituzionale, n. 2, p. 1-15, 2020b. Disponível em: https:// www.gruppodipisa.it/images/rivista/pdf/Roberto_Romboli_-_Il_sistema_di_ costituzionalita_tra_momenti_di_accentramento_e_momenti_di_diffusione. pdf. Acesso em: 24 out. 2021.

ROMBOLI, Roberto. L'incidenza della pandemia da coronavirus nel sistema costituzionale italiano. Consulta online, n.3, p.513-544, 2020c. Disponível em: https://www.giurcost.org/studi/romboli6.pdf. Acesso em: 24 out. 2021.

ROMBOLI, Roberto; ROSSI, Emanuele. Giudizio di legittimità costituzionale delle leggi. In: ENCICLOPEDIA del diritto. Milano: Giuffrè, 2001. v. 18.

RUGGERI, Antonio. Il valore di "unità-autonomia" quale fondamento e limite dei giudizi in via d'azione e della "specializzazione" dell'autonomia regionale (prime notazioni). Rivista Gruppo di Pisa, 03/2020a. La Rivista Gruppo di Pisa: Dibattito aperto sul Diritto e la Giustizia Costituzionale, n. 3, p. 100-110, 2020. Disponível em: https://www.gruppodipisa.it/images/rivista/pdf/ Antonio_Ruggeri_-_Il_valore_di_unita-autonomia_quale_fondamento_e_ limite_dei_giudizi_in_via_d_azione.pdf. Acesso em: 24 out. 2021. 
SALES, Isaia. Le regioni italiane fanno male alla salute (anche prima del Covid). Domani, 21 out. 2020. Disponível em: https://www.editorialedomani.it/ politica/italia/le-regioni-italiane-fanno-male-alla-salute-anche-prima-delcovid-vg8dpt8a. Acesso em: 2 jan. 2021.

SPADARO, Antonio. Dalla "democrazia costituzionale" alla "democrazia illiberale" (populismo sovranista), fino alla.... "democratura”. DPCE Online, v. 44, n. 3, p. 3875-3898, oct. 2020. Disponível em: http://www.dpceonline.it/ index.php/dpceonline/article/view/1097. Acesso em: 26 set. 2021.

TEGA, Dileta. La Corte nel contesto: percorsi di ri-accentramento della giustizia costituzionale in Italia. Bologna: Bononia University Press, 2020. 384 p.

WALDRON, Jeremy. The rule of law. In: ZALTA, Edward N. (ed.). Stanford Encyclopedia of Philosophy. Summer ed. [Stanford: Stanford University], 2020. Disponível em: https://plato.stanford.edu/entries/rule-of-law/. Acesso em: 21 jun. 2021.

ZAGREBELSKY, Gustavo. La legge e la sua giustizia: tre capitoli di giustizia costituzionale. Bologna: Il Mulino, 2012.

\section{Jurisprudência citada}

BRASIL. Supremo Tribunal Federal (Tribunal Pleno). Ação Direta de Inconstitucionalidade 3.406/RJ. Relatora: Min. Rosa Weber, 29 de novembro de 2017. Diário da Justiça Eletrônico: Supremo Tribunal Federal, n. 278, p. 135, 4 dez. 2017. Disponível em: https://www.stf.jus.br/arquivo/djEletronico/ DJE_20171201_278.pdf. Acesso em: 26 out. 2021.

BRASIL. Supremo Tribunal Federal (Tribunal Pleno). Ação Direta de Inconstitucionalidade 3.470/RJ. Relatora: Min. Rosa Weber, 29 de novembro de 2017. Disponível em: https://redir.stf.jus.br/paginadorpub/paginador. jsp?docTP=TP\&docID=749020501. Acesso em: 11 nov. 2021.

BRASIL. Supremo Tribunal Federal (Decisão Monocrática). Medida Cautelar na Ação Direta de Inconstitucionalidade 6.341/DF. Relator: Min. Marco Aurélio, 24 de março de 2020. Diário da Justiça Eletrônico: Supremo Tribunal Federal, n. 72, 26 mar. 2020. Disponível em: http://stf.jus.br/portal/diarioJustica/verDecisao.asp? numDj=72\&data Publicacao $=26 / 03 / 2020 \&$ incidente $=5880779 \&$ capitulo $=6 \&$ codigo Materia $=2 \&$ numeroMateria $=37 \&$ texto $=8738565$. Acesso em: 11 nov. 2021 . 
BRASIL. Supremo Tribunal Federal (Decisão Monocrática). Medida Cautelar na Ação Direta de Inconstitucionalidade 6.625/DF. Relator: Min. Ricardo Lewandowski, 30 de dezembro de 2020. Disponível em: http://portal.stf.jus. br/processos/downloadPeca.asp?id=15345351846\&ext=.pdf. Acesso em: 11 nov. 2021.

BRASIL. Supremo Tribunal Federal (Decisão Monocrática). Medida Cautelar na Arguição de Descumprimento de Preceito Fundamental 672/DF. Relator: Min. Alexandre de Moraes, 8 de abril de 2020. Disponível em: http://portal. stf.jus.br/processos/downloadPeca. asp?id=15342867936\&ext=.pdf. Acesso em: 11 nov. 2021.

BRASIL. Supremo Tribunal Federal (Tribunal Pleno). Referendo na Medida Cautelar na Ação Direta de Inconstitucionalidade 6.341/DF. Relator: Min. Marco Aurélio. Redator para o acórdão: Min: Edson Fachin, 15 de abril de 2020. Disponível em: https://redir.stf.jus.br/paginadorpub/paginador. jsp?docTP=TP\&docID=754372183. Acesso em: 11 nov. 2021.

BRASIL. Supremo Tribunal Federal (Tribunal Pleno). Referendo na Medida Cautelar na Ação Direta de Inconstitucionalidade 6.625/DF. Relator: Min. Ricardo Lewandowski, 8 de março de 2021. Disponível em: https://redir.stf. jus.br/paginadorpub/paginador.jsp?docTP=TP\&docID=755551305. Acesso em: 11 nov. 2021.

BRASIL. Supremo Tribunal Federal (Tribunal Pleno). Referendo na Medida Cautelar na Arguição de Descumprimento de Preceito Fundamental 672/DF. Relator: Min. Alexandre de Moraes, 13 de outubro 2020. Disponível em: https:// redir.stf.jus.br/paginadorpub/paginador.jsp?docTP=TP\&docID $=754239592$. Acesso em: 11 nov. 2021.

ITÁLIA. Corte Costituzionale. Sentenza n. 37/2021. Disponível em: https:// www.cortecostituzionale.it/actionSchedaPronuncia.do?anno=2021\&numero=37. Acesso em: 27 out. 2021. 


\section{Legislação citada}

BRASIL. Ato Institucional no 5, de 13 de dezembro de 1968. São mantidas a Constituição de 24 de janeiro de 1967 e as Constituições Estaduais; O Presidente da República poderá decretar a intervenção nos estados e municípios, sem as limitações previstas na Constituição, suspender os direitos políticos de quaisquer cidadãos pelo prazo de 10 anos e cassar mandatos eletivos federais, estaduais e municipais, e dá outras providências. Brasília, DF: Presidência da República, [1969]. Disponível em: http://www.planalto.gov.br/ccivil_03/ait/ait-05-68.htm. Acesso em: 25 out. 2021.

BRASIL. [Constituição (1988)]. Constituição da República Federativa do Brasil de 1988. Brasília, DF: Presidência da República, [2021]. Disponível em: http://www.planalto.gov.br/ccivil_03/constituicao/constituicao.htm. Acesso em: 23 out. 2021 .

BRASIL. Decreto-Legislativo no 6, de 20 de março de 2020. Reconhece, para os fins do art. 65 da Lei Complementar no 101, de 4 de maio de 2000, a ocorrência do estado de calamidade pública, nos termos da solicitação do Presidente da República encaminhada por meio da Mensagem no 93, de 18 de março de 2020. Brasília, DF: Presidência da República, [2020]. Disponível em: http://www. planalto.gov.br/ccivil_03/portaria/DLG6-2020.htm. Acesso em: 25 out. 2021.

BRASIL. Lei no 8.080, 19 de setembro de 1990. Dispõe sobre as condições para a promoção, proteção e recuperação da saúde, a organização e o funcionamento dos serviços correspondentes e dá outras providências.. Brasília, DF: Presidência da República, [2021]. Disponível em: http://www.planalto.gov.br/ccivil_03/leis/ 18080.htm. Acesso em: 25 out. 2021.

BRASIL. Lei no 13.979, de 6 de fevereiro de 2020. Dispõe sobre as medidas para enfrentamento da emergência de saúde pública de importância internacional decorrente do coronavírus responsável pelo surto de 2019. Brasília, DF: Presidência da República, [2021]. Disponível em: http://www.planalto.gov.br/ ccivil_03/_ato2019-2022/2020/lei/113979.htm. Acesso em: 23 out. 2021. 
BRASIL. Lei no 14.035, de 11 de novembro de 2020. Altera a Lei no 13.979, de 6 de fevereiro de 2020, para dispor sobre procedimentos para a aquisição ou contratação de bens, serviços e insumos destinados ao enfrentamento da emergência de saúde pública de importância internacional decorrente do coronavírus responsável pelo surto de 2019. Brasília, DF: Presidência da República, [2021]. Disponível em: http://www.planalto.gov.br/ccivil_03/_ato20192022/2020/lei/114035.htm. Acesso em: 25 out. 2021.

BRASIL. Medida Provisória no 926, de 20 de março de 2020. Altera a Lei $\mathrm{n}^{\circ} 13.979$, de 6 de fevereiro de 2020, para dispor sobre procedimentos para aquisição de bens, serviços e insumos destinados ao enfrentamento da emergência de saúde pública de importância internacional decorrente do coronavírus. Brasília, DF: Presidência da República, [2020]. Convertida na Lei No 14.035, de 11 de novembro de 2020. Disponível em: http://www.planalto.gov.br/ccivil_03/_ ato2019-2022/2020/Mpv/mpv926.htm. Acesso em: 25 out. 2021.

ITÁLIA. [Constituição (1947)]. Constituição da República Italiana. Milão: Servizio degli Affari Internazionali do Senado da República, 2018. Disponível em: https://www.senato.it/sites/default/files/media-documents/COST_ PORTOGHESE.pdf. Acesso em: 25 out. 2021.

ITÁLIA. Decreto Legislativo no 1 , del 2 gennaio 2018. Codice della protezione civile. Roma: Repubblica italiana, [2018]. Disponível em: https://www. protezionecivile.gov.it/en/normativa/decreto-legislativo-n-1-del-2-gennaio2018--codice-della-protezione-civile. Acesso em: 25 out. 2021.

ITÁLIA. Regione Valle d'Aosta. Legge regionale [Valle d'Aosta] n. 11, del 9 dicembre 2020. Misure di contenimento della diffusione del virus SARS- COV-2 nelle attività sociali ed economiche della Regione autonoma Valle d'Aosta in relazione allo stato di emergenza. [2020?]. Disponível em: https://www.frareg. com/cms/wp-content/uploads/2020/12/LR_Valle-Aosta_11_09122020.pdf. Acesso em: 26 out. 2021.

ITÁLIA. Decreto-Legge no 2, 14 gennaio 2021. Ulteriori disposizioni urgenti in materia di contenimento e prevenzione dell'emergenza epidemiologica da COVID-19 e di svolgimento delle elezioni per l'anno 2021. Gazzetta Ufficiale della Repubblica Italiana, v. 162, n. 10, p. 1-3, 14 gennaio 2021. Disponível em: https://www.gazzettaufficiale.it/eli/gu/2021/01/14/10/sg/pdf. Acesso em: 25 out. 2021. 
ITÁLIA. Decreto-Legge n⿳ 6, 23 febbraio 2020. Misure urgenti in materia di contenimento e gestione dell'emergenza epidemiologica da COVID-19. Roma: Repubblica italiana, [2020]. Disponível em: http://www.prefettura.it/FILES/ AllegatiPag/1201/decreto_legge_n._6_del_23.02.2020.pdf. Acesso em: 26 out. 2021.

ITÁLIA. Decreto-Legge no 19, 25 marzo 2020. Misure urgenti per fronteggiare l'emergenza epidemiologica da COVID-19. Gazzetta Ufficiale della Repubblica Italiana, v. 161, n. 79, p. 1-4, 25 marzo 2020. Disponível em: https://www.gazzettaufficiale.it/do/gazzetta/downloadPdf?dataPubblicazione Gazzetta $=20200325 \&$ numeroGazzetta $=79 \&$ tipoSerie $=$ SG\&tipoSupplemento $=$ GU\&numeroSupplemento $=0 \&$ progressivo $=0 \&$ estensione $=$ pdf\&edizione $=0$. Acesso em: 26 out. 2021.

ITÁLIA. Ordinanza Sindacale n. 105 del 5 aprile 2020. Ordinanza contingibile e urgente ex art. 50 D. Lgs. 267/2000. Misure urgenti per l'attuazione dei D.P.C.M. 8/3/2020, D.P.C.M. 9/3/2020 e D.P.C.M. 11/3/2020. Attraversamento dello Stretto di Messina attivazione del sistema di prenotazione on-line www. sipassaacondizione.comune.messina.it. Revoca Ordinanza Sindacale n. 80 del 26 marzo 2020 e disciplina utilizzo banca dati finalizzata alla verifica delle condizioni per l'attraversamento dello Stretto. [2020]. Disponível em: https:// comune.messina.it/wp-content/plugins/allegati-rev2/includes/download.php?id $=77067$. Acesso em: 26 out. 2021 .

ITÁLIA. Corte Costituzionale. Ordinanza no 4, de 14 de janeiro de 2021. [2021] Disponível em: https://www.camera.it/temiap/2021/01/15/OCD177-4759.pdf. Acesso em: 26 out. 2021.

ITÁliA. Ordinanza no 207, de 2018. Disponível em: https://www. cortecostituzionale.it/actionPronuncia.do\#scheda. Acesso em: 26 out. 2021. 